\title{
المسيح في شعر السياب ومحمود درويش
}

\section{م.هيام عبد الكاظم ابراهيم - جامعة \\ القادسية أنمانة}

\section{Conclusion}

Christian religious symbols and masks the large number of notable abounded in the notice Sayyab and Mahmoud Darwish, which are often symbols directly did not need an effort to elucidate the most prominent of these symbols (rice Christ) and symbolized by the person who sacrifice for the sake of his country and its people has been symbolized by also to the entire people.

And fall under the symbol other symbols connected by branched him such as the cross or steel crown thorns refers steel to the burden of sacrifice and suffering long and pains, remains unchanged poet suffers from his ordeal on the cross motivated by altruism and resistance to happiness and salvation reflected those meanings clearly in the poems.

الحمد لله رب العالمين و الصلاة و السلام على أثرف المرسلين و على آله وصحبه المنتجبين . لابد من مدخل يكون توطئة لهذا البحث قبل الولولج في مادته ، لقد أحس الشعر اء بضرورة الابتعاد

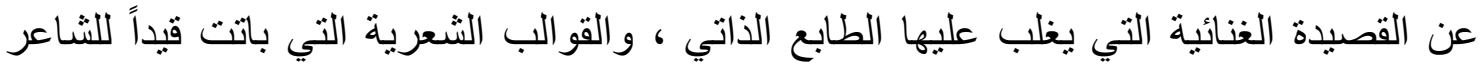

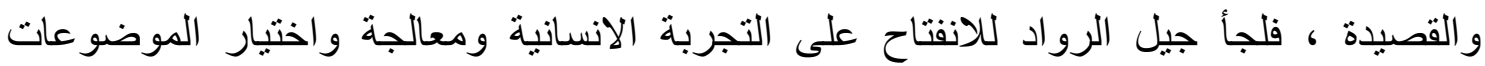

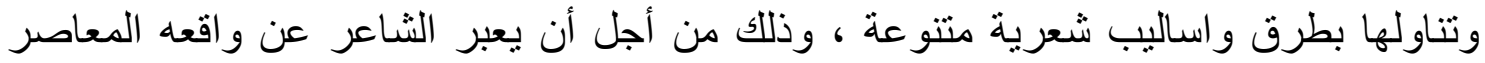

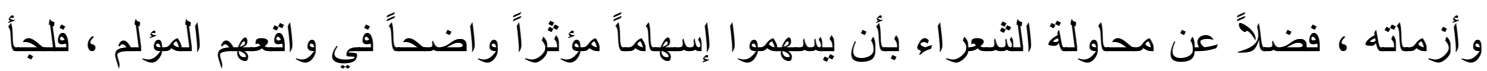

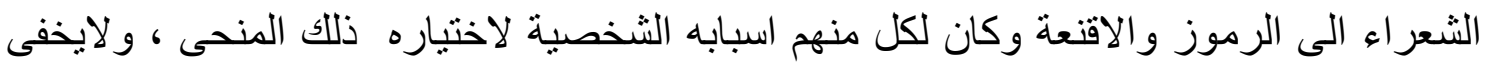

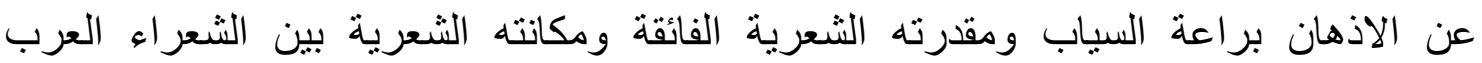

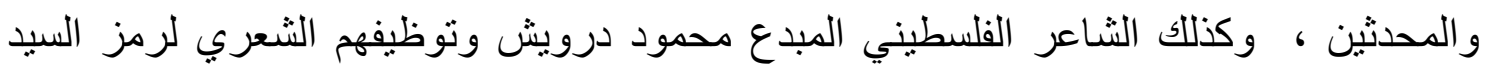

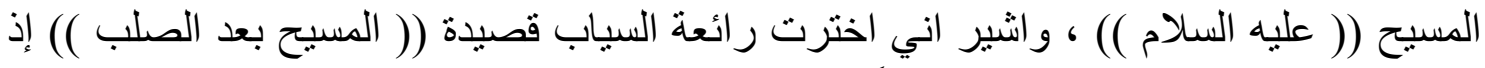

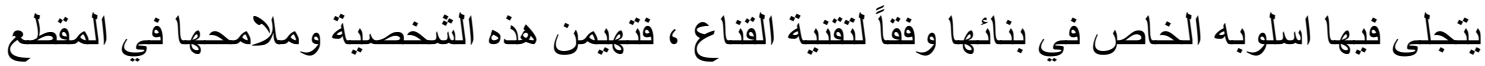

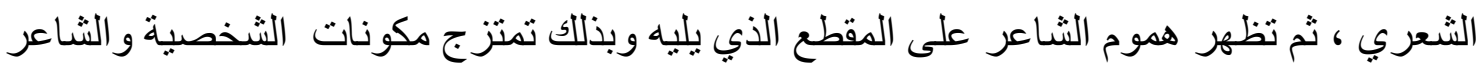




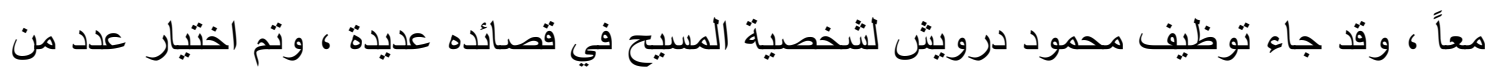

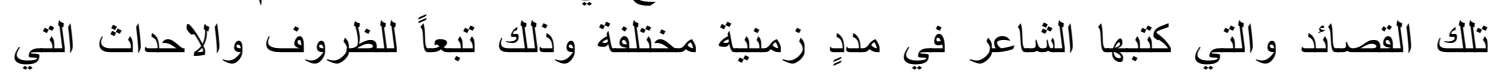
عاصر ها الثاعر ، وقد جاء البحث على مبحثين :

الاول و الموسوم ((المسيح في شعر السياب))عرضت فيه توظيف السياب لشخصية المسيح في

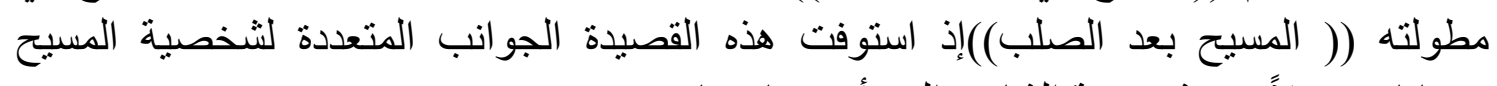

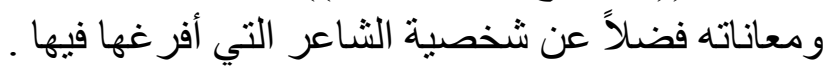

أما المبحث الثاني وهو موسوم (( المسيح في شعر محمود درويش )) فقد خاض مضمار

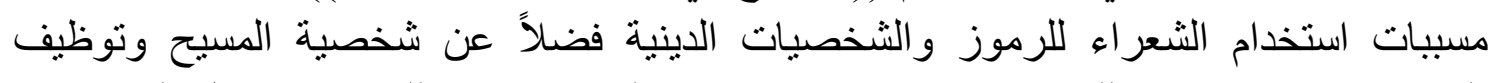

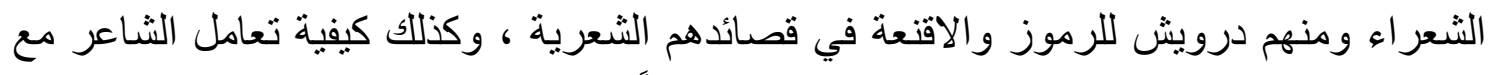

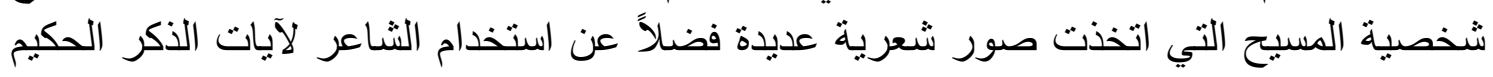

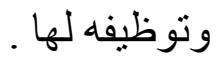

$$
\text { المبحث الاول }
$$

المسيح في شعر السياب

شكل الاداء بـ((القناع تصويرًا )) اتجاها سائداً ويرتكز على العنصر التصويري ، إذ يقوم

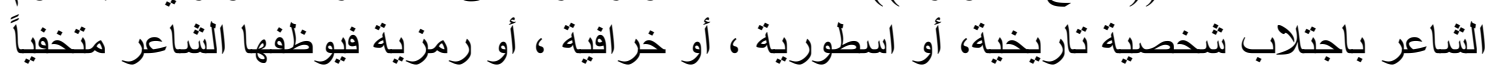

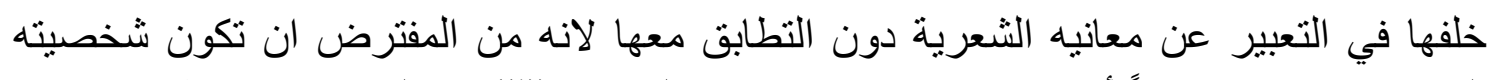

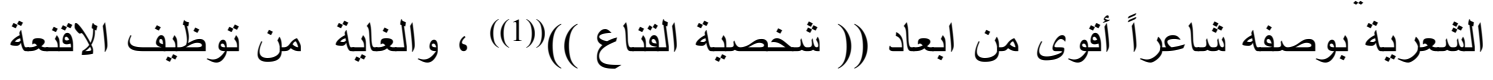

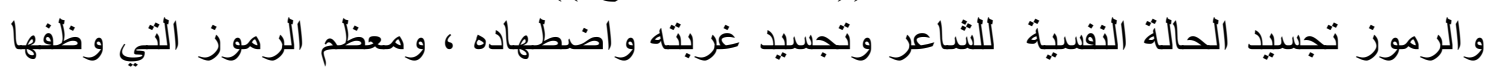

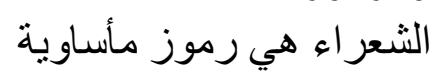

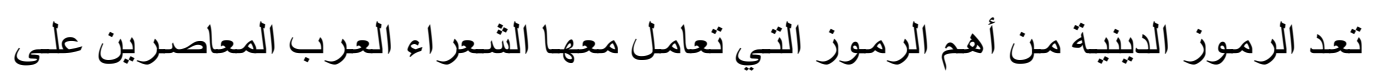

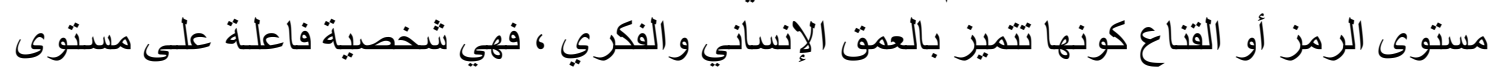

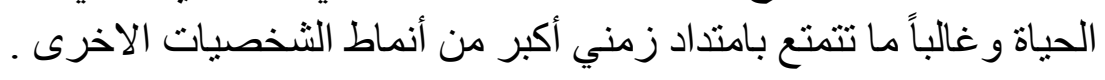

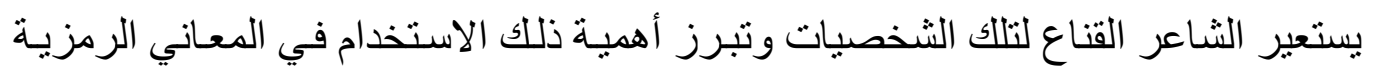

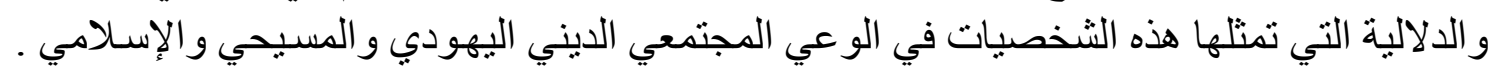

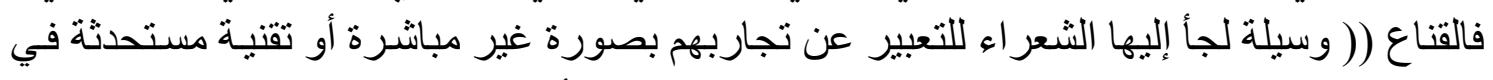

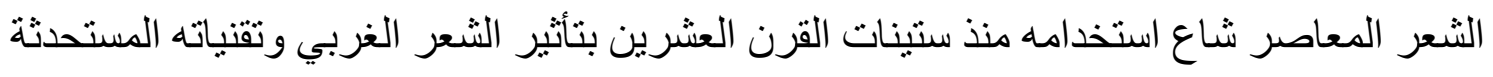

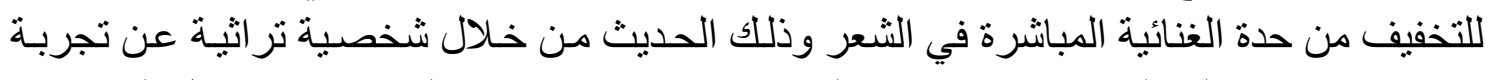
معاصرة بضمير المتكلم و هكذا يندمج في القصيدة صـونان : صـوت الثـاعر من خـلال الثخصية 


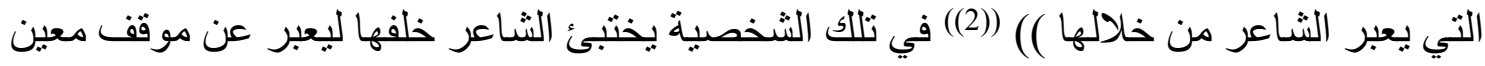

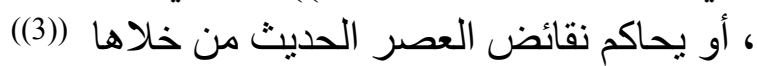

و القناع لايخرج عن إطار الرمز تماماً ، ويتوحد الثاعر مع رمزه في القناع بشكل تام.

أما في حالة الرمز فيكون منفصلاً عنه ويعبر عن جانب معين من تجربته ، فالقناع مغزى القصيدة

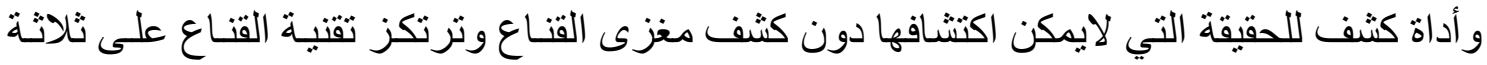

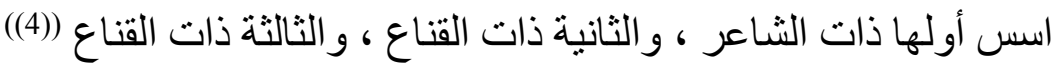

ويصفه الثاعر عبد الوهاب البياتي بأنـه : (( الاسـم الذي يتحدث من خلاله الثـاعر نفسـهـ

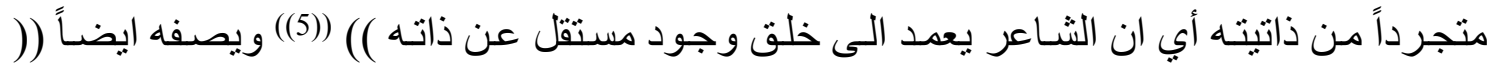

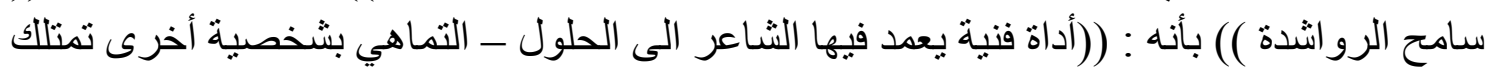

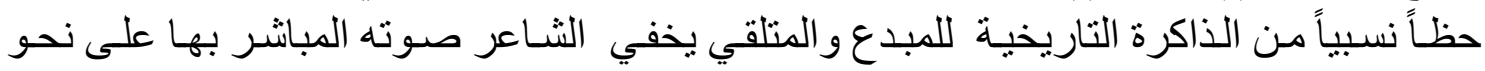

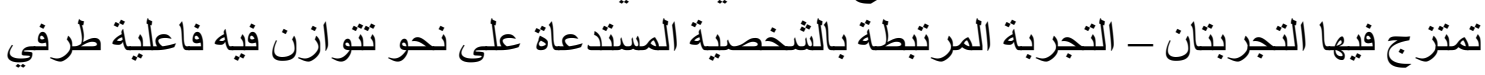

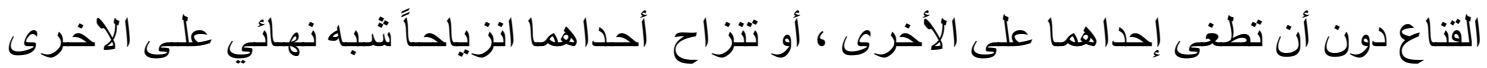
$((6))(($

وفي قصيدة القناع يكون بإمكان الثـاعر أنْ بلجـأ لأكثر من بنـاء فني عند صياغة قصيدة

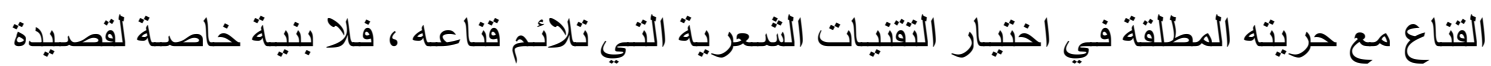

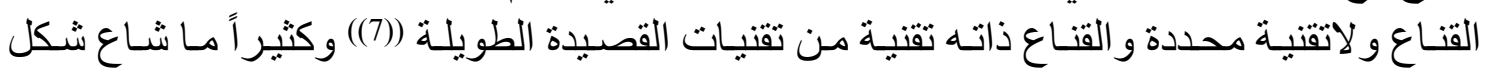

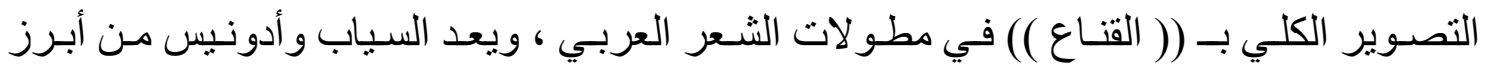

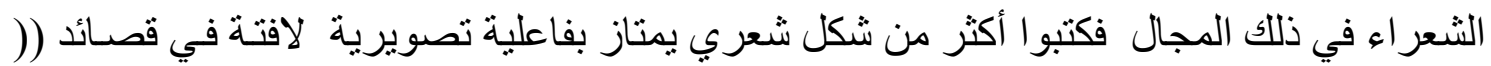

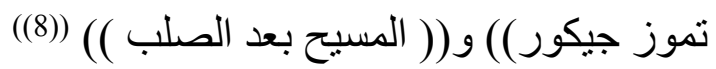
ان القنـاع في الثـعر العربـي الحديث ظـاهرة مهمـة مـن ظو اهره وأداة استخدمها الثــاعر

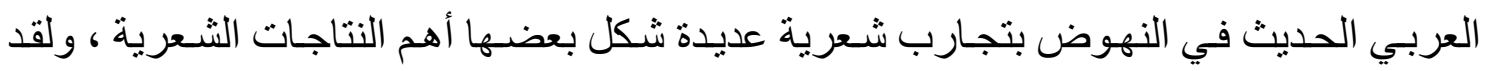

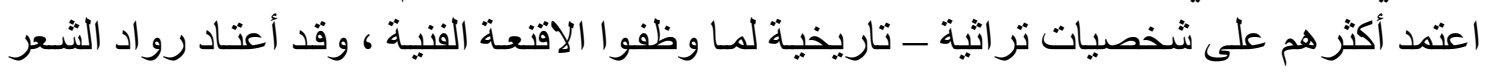

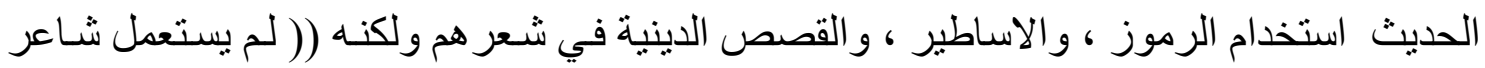

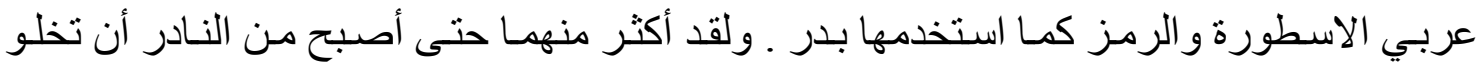

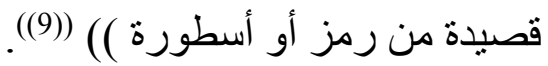

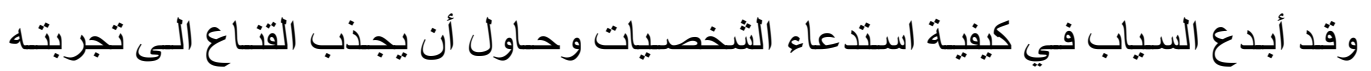
ويستلهم صوته وتجربته ويتقص شخصية القناع ويؤدي دور ها للتعبير عن و اقع وتجربة معاصرة

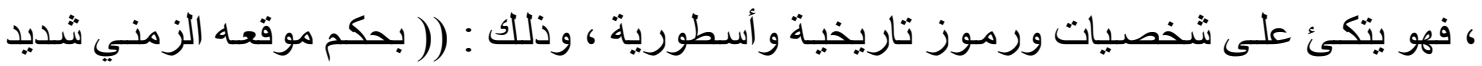

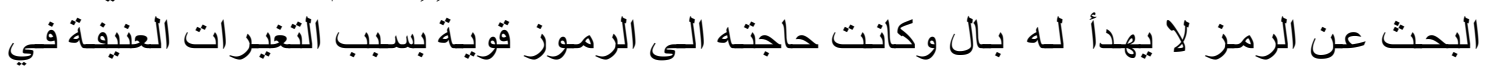


المسرح السياسي بالعر اق حينئذ ... و السياب قد فتح المجال بعده لمن شـاء أن يستخدم الرموز و إن تجاوزه بعضهم في القدرة على الاختيار وفي طريقة الاستخدام )( (10)).

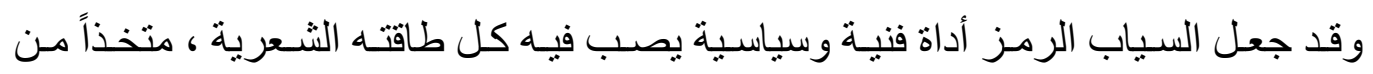

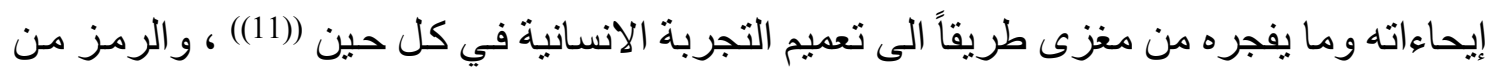

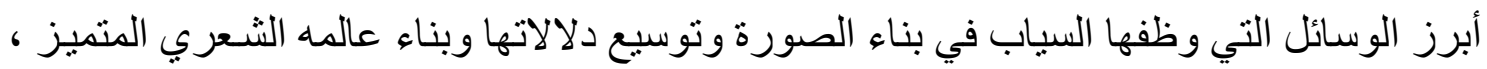

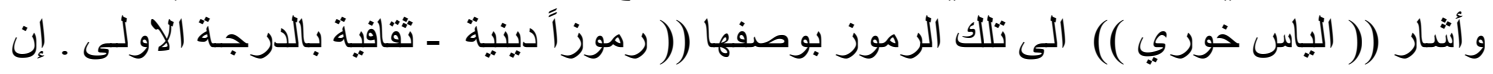

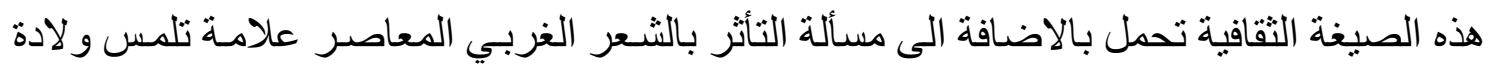

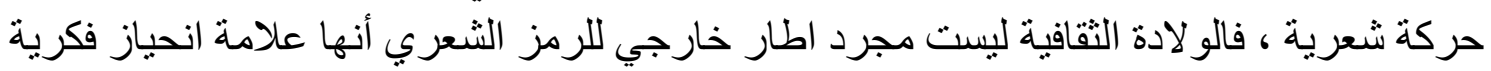

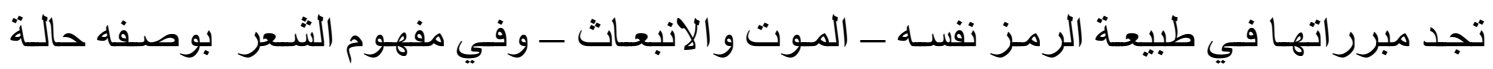
حضارية)) ((12)) ، وقد علل السباب لجوئه الى الرمز بـ بـالظروف السياسية التي نشـأت في البلدان

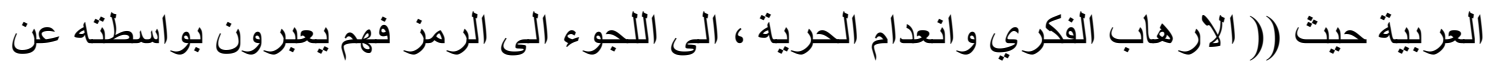

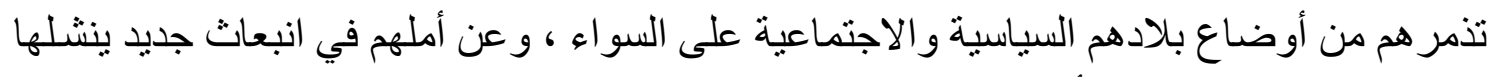

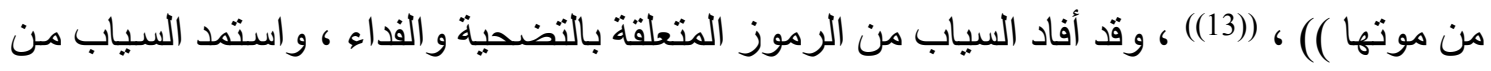

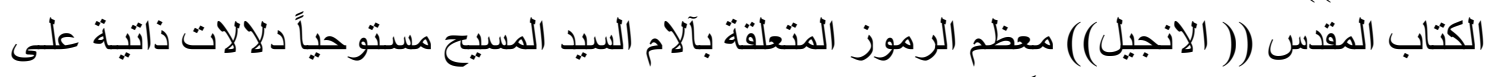

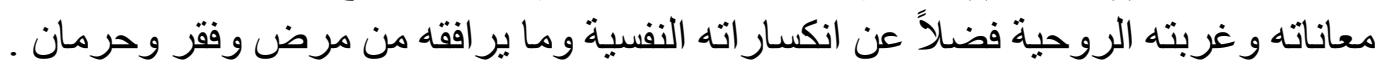

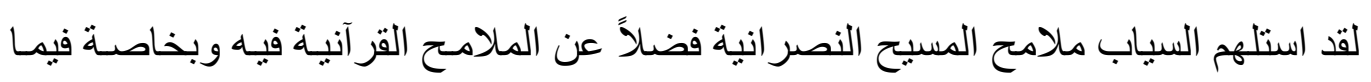
يتعلق بالصلب ، و الفداء ، و الحياة من خلال الموت ، و تحفل قصائد السياب بالعديد من القضايا التي

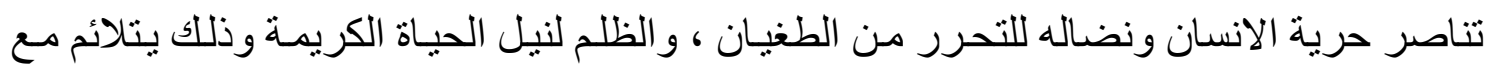

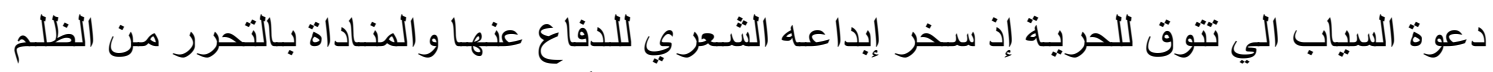

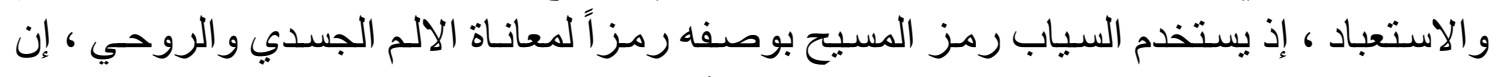

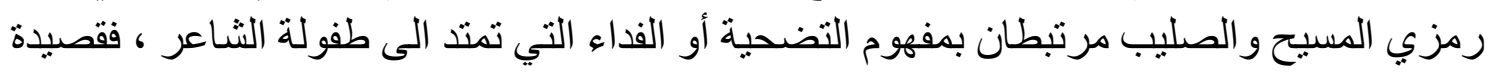

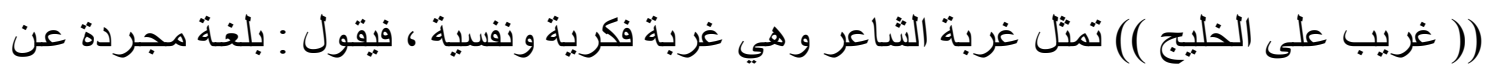
شوقه للعر اق : بين القرى المتهيبات خطاي ، ، والمدن الغريبة غنيت ترتبك الحبيبة وحملتها فأنا المسيح يجر في المنفى صليبه ((14))

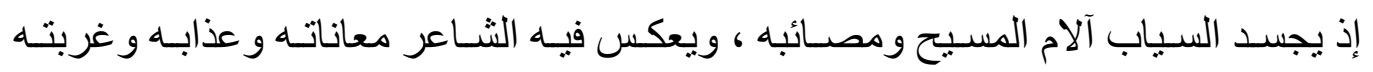
الروحية من خلال توظيفه ، الصليب أو صليب الإل المسيح . وفي (( قافلـة الضـياع )) يخاطب الثـعوب واللاجئـين ومأسـاة الفلسـينيين للتعبيـر عـن 
كان المسيح بجنبه الدامي ومئزره العتيق

ومئزره العتيق يسد ما حفرته ألسنة الكلاب

فاجتاحه الطوفان - حتى ليس ينزف منه جنب أو جبين

الادجى كالطين تبنى منه دور اللاجئين ((15))

وتعبر قصيدة (( مرحى غيلان)) عن الدم ، و الدموع ، و الموت ، و الحياة يقول:

الموت يركض في شوار عها ويهتف : يانيام

بانيام

هبو ا فقد ولد الظلام و أنا المسيح أنا السلام (16))

مزج السياب عنصـر الو لادة مـع المـوت و الظـلام ، و النور، و اليأس ، و الأمل معـاً ، فإنـه

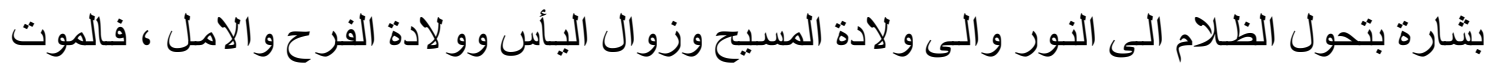
تجربة عنيفة في شعر السياب فهو ينظر للاشياء من منظور الموت ، وربما كانت الاشياء في نظره ثنائية ضدية و انهما نقيضنان هما الموت و الحياة ، الغربة موت و الوجود في الوطن حياة((17)).

وقصيدة ((المسيح بعد الصلب )) هي البداية الناضجة الأولى لفكرة القصيدة القناع ، وتعد

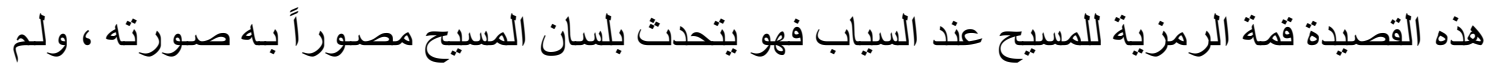

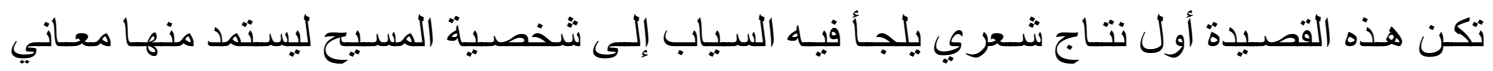

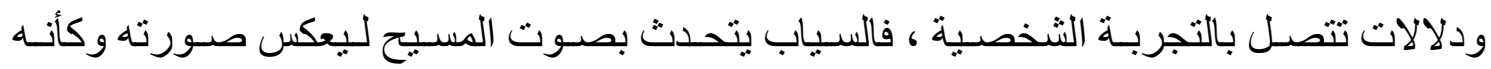

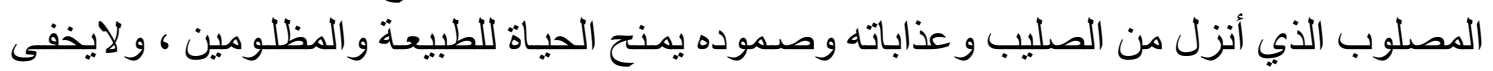

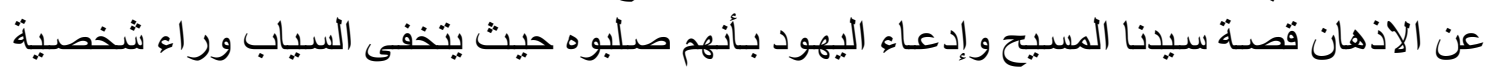
المسيح ويحكي قصته و معاناته من خلالها وتمكن أن يمزج تللك الثخصية الدينية في نصه الثـعري الثهاء

وتعتبر قصيدة (( المسيح بعد الصلب )) أنموذجاً رفيعـاً من قصـائد القناع ، فهي تصور

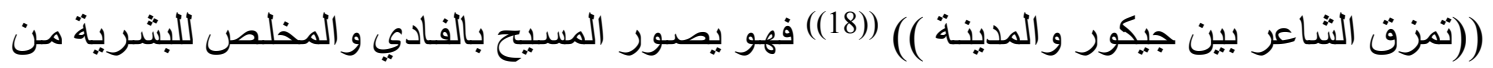

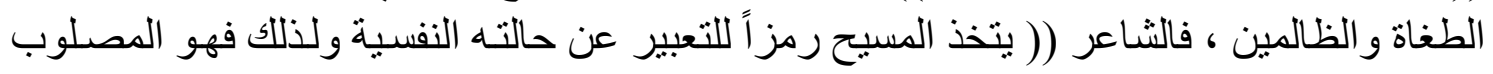

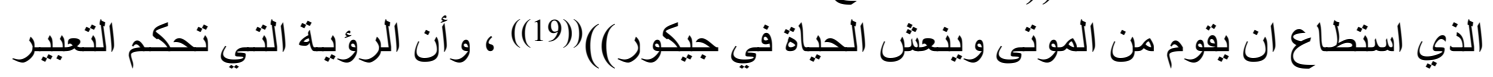

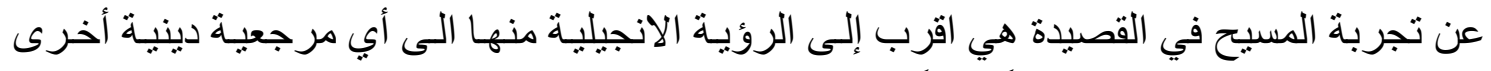

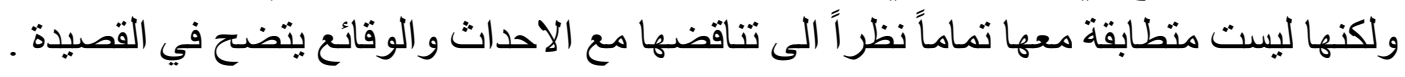




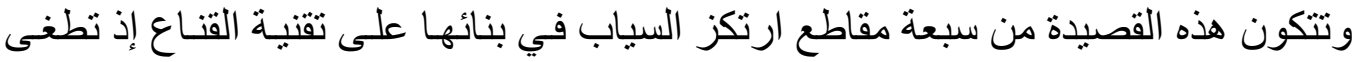

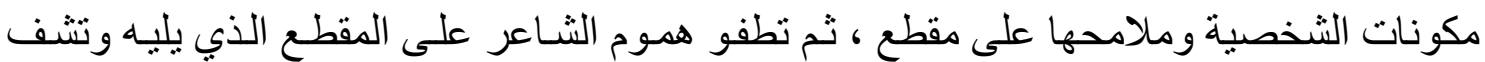

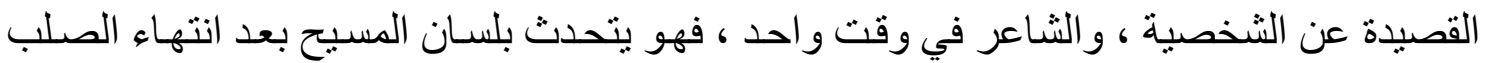

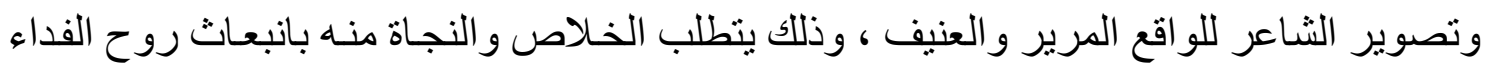
من المسيح وديمومة الحياة .

فيقول الثاعر في المقطع الاول : بعدما أنزلوني ، سمعت الرياح في نو اح طويل تسف النخيل و الخطى و هي تنأى ـ إذن فالجر اح و الصليب الذي سمروني عليه طو ال الأصيل لم تمنتي ـ و أنصت : كان العويل يعبر السهل بيني و بين المدينه

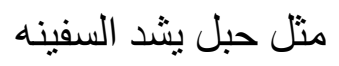
وهي تهوي إلى القاع ـ كان النواح مثل خيط من النور بين الصباح و الاجى ، في سماء الثتاء الحزينه. ثم تغفو ، على ما تحس ، المدينه (20)().

يبدأ المقطع الأول من القصيدة بمشهذ يصور نهاية عمليـة الصلب التي تعرض لها السبد

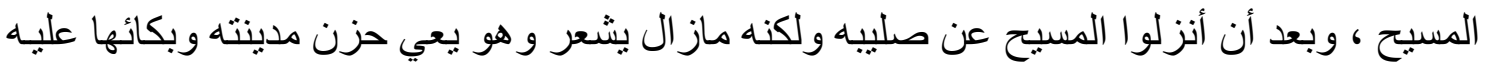

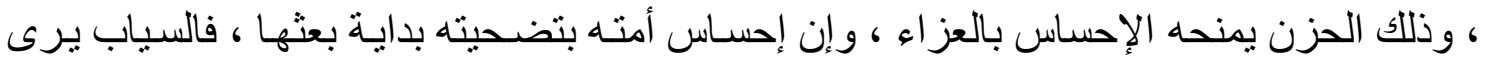

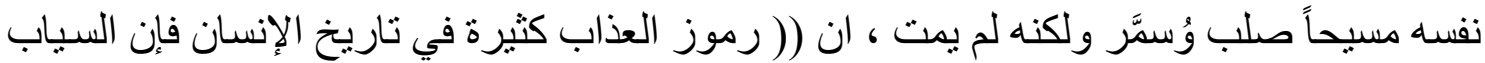

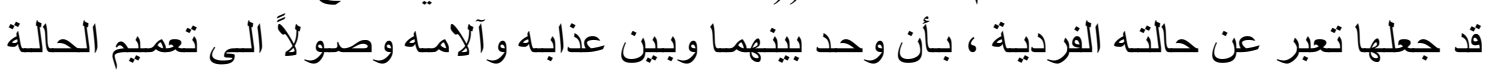

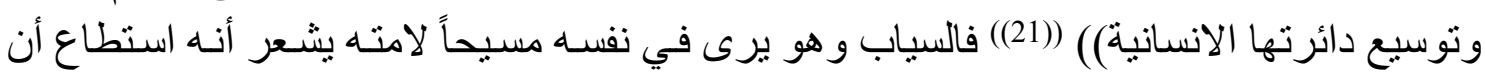

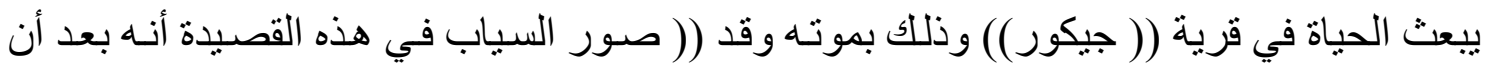

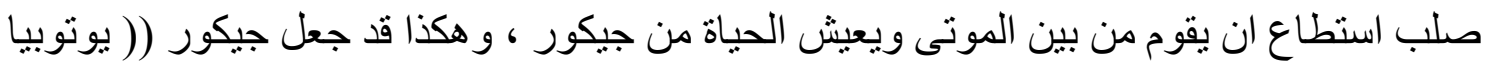


السيابية )) عندما يلمس الدفه قلبه يجري دمـه في ثر اهـا لان قلبه هو الثـس التي تنبض بـالنور

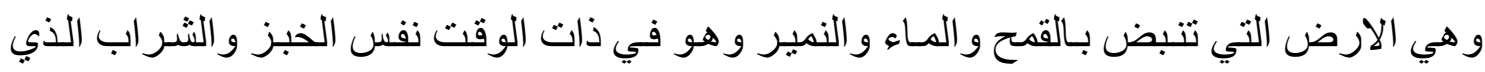

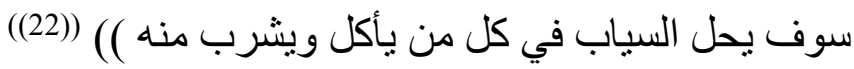

فالسياب استلهم شخصية المسيح في القصيدة لتكون (( قناع شفاف ، ويتحدث من خـلال

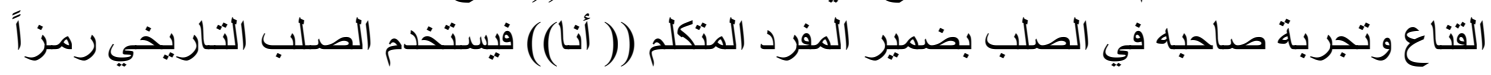

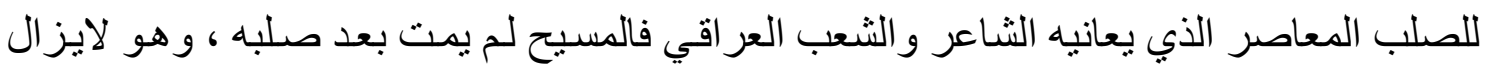
يسمع الرياح تعصف بنخيل العر اق ويصل الى أسماعه عويل المعذبين )( (23)) بعديه

لقد استخدم السياب الألفاظ (( نوح - جر اح - تسقى - سمروني - تمتني - العو ايل ))

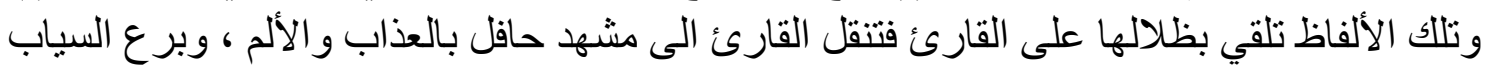

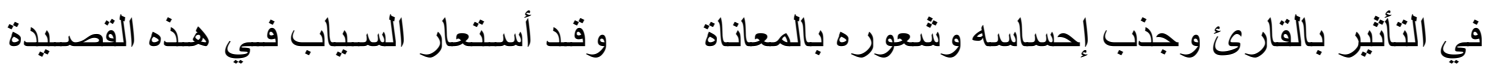

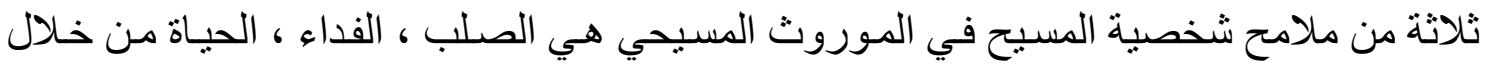

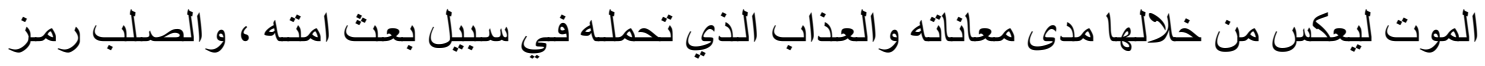

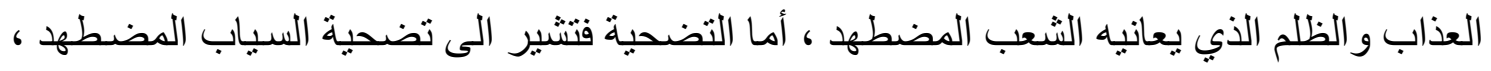

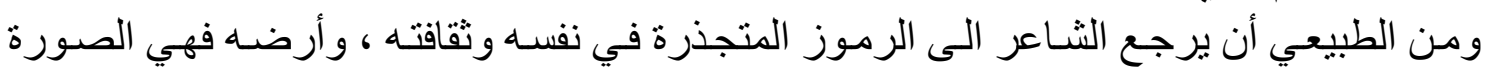

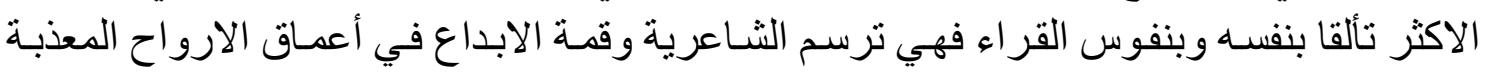
بقمع الظالمين ((24)) ويرسم السياب في المقطع الثاني لوحة شاعرية جميلة لقريته جيكور ، فالشاعر

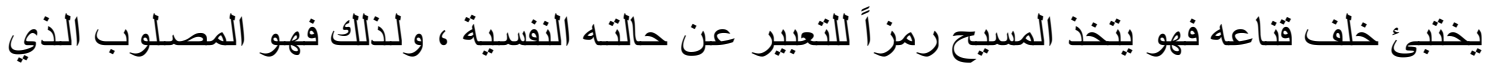

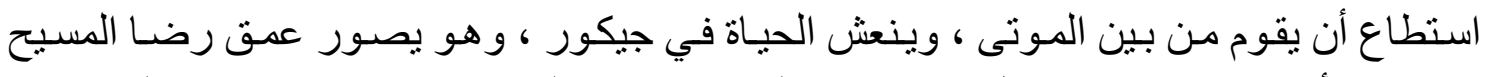

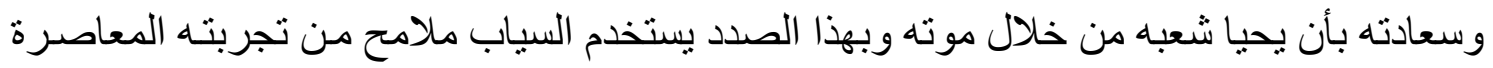

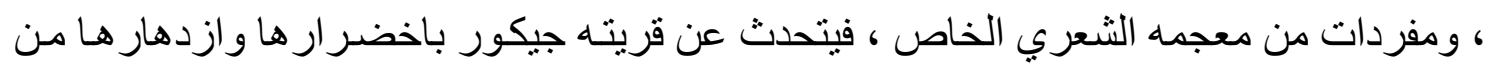

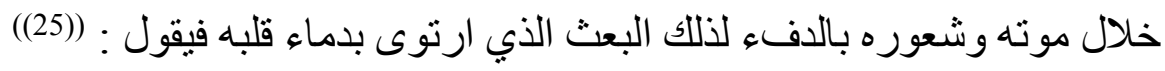

$$
\text { قلين يخضرّ حتى دجاها }
$$




$$
\begin{aligned}
& \text { في العجين الذي بستدير } \\
& \text { ويدحى كنهد صغير كثدي الحياة } \\
& \text { مثتّ بالنار أحرقت ظلماء طيني فظلّ الإله ((26)) }
\end{aligned}
$$

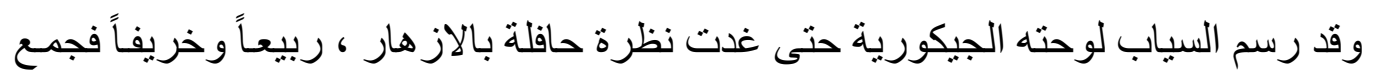

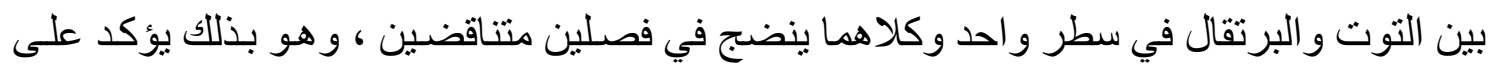
ديمومة وسرمدية الاخضر ار في جيكور و غدت في ربئ وبيع دائم .

ولقد وظف الثـاعر دلالـة اللون الأخضر في تكوين لوحته العشرية واللون الاخضـر لله

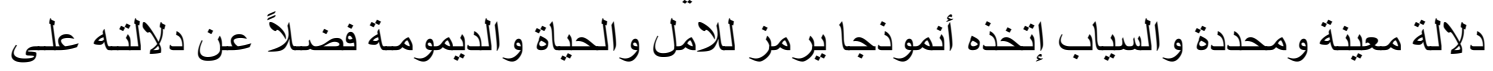

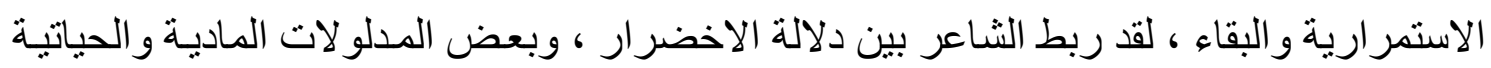

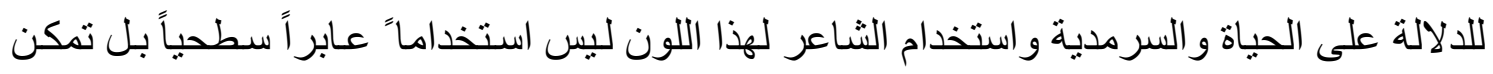

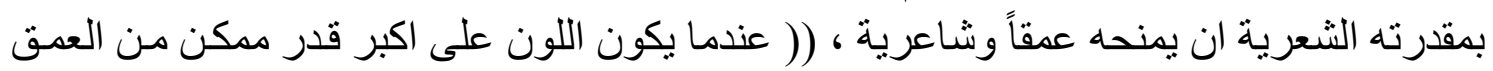

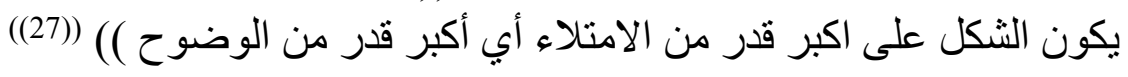

و أجاد الشاعر في توظيفه للون في لوحته الجيكورية ومنحه عمقاً ، و لايخفى عن الاذهـان

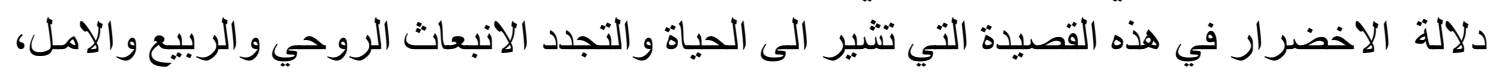
ودلالة الاخضر ار تتفق عليها أغلب الديانات الموحدة كالديانة المسيحية والاسلامية. (28))

وذللك يدلل على إن المورد اللوني لاى الثـاعر هو مورد معبر عن سرمدية الحياة والامل ،

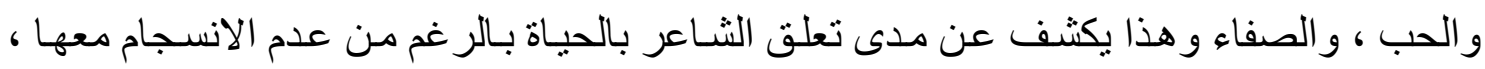
وييلغ السياب حالة من التوحد مع جيكور فيقول : (( يلمس الدف قلبي ، فيجري دمسي في ثر اهـا ))

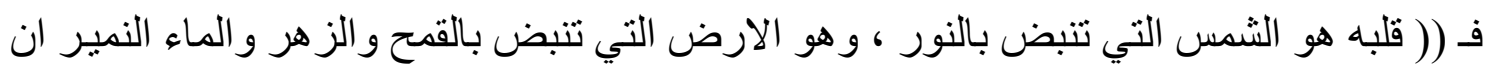

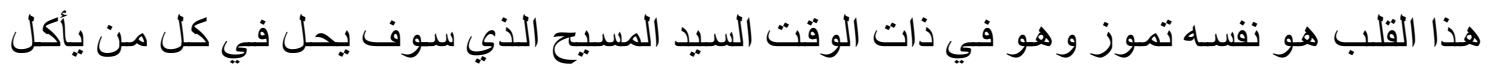

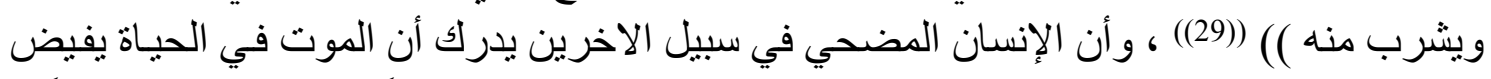

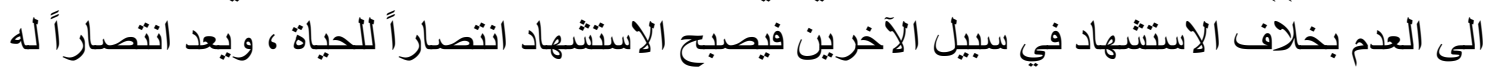

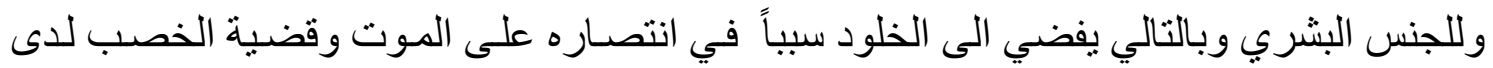

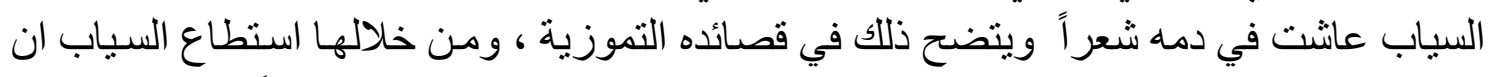

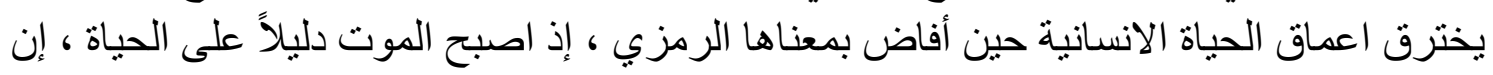

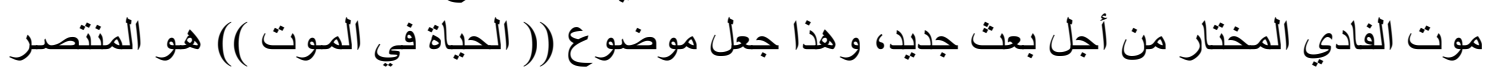

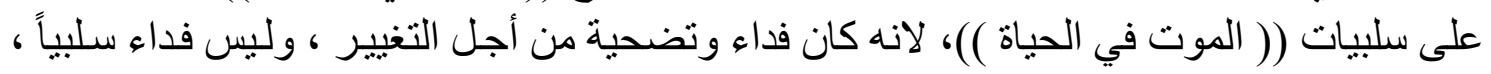
و إن تضحية تموز كانت تضحية بطولية فهي ايجابية التحمل و العطاء لاقدريـة مفروضـة فئة ، فالمسيح 
أعطى دمه دن أجل الناس جميعاً وفكرة التضحية نجدها عند السياب فهو يوحد بينه وبين المسيح وتموز ويرى أن دمه قد صار في كل قلب حتى استشهاده ((30))

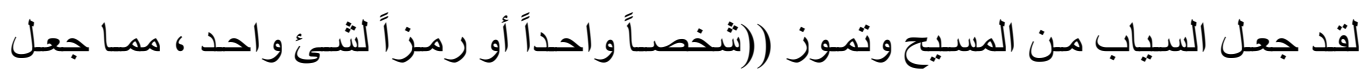

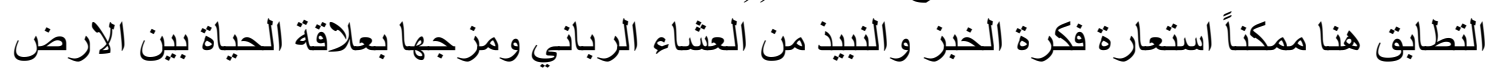

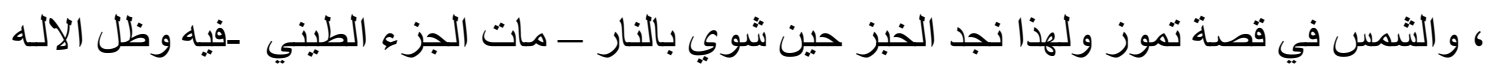

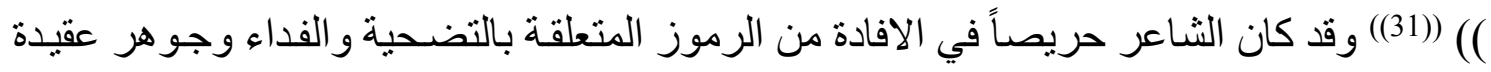

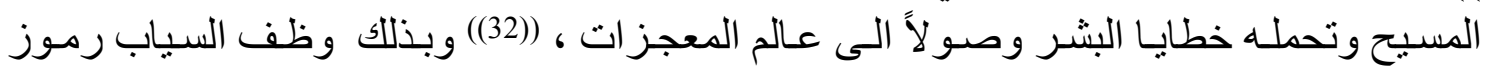

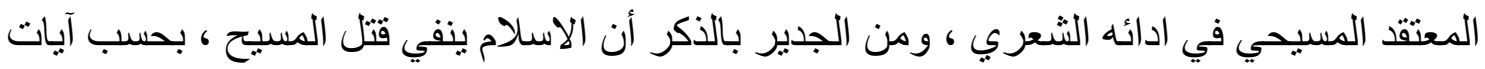

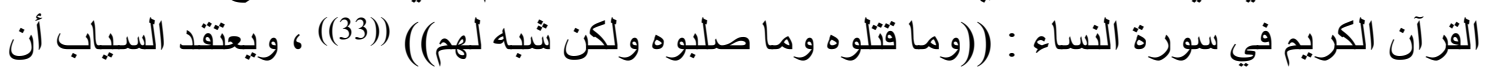

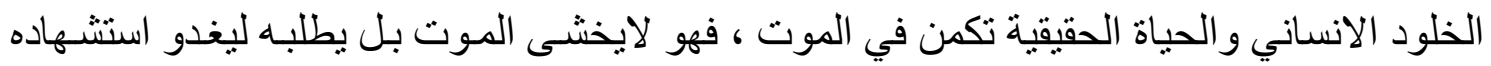

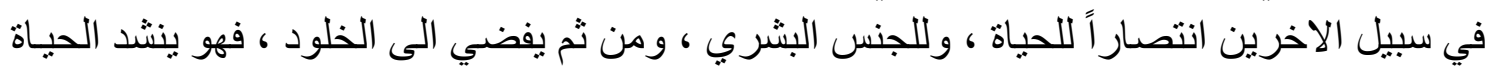
في الموت على إثر فكرتين : الاولى فكرة التضحية المسيحية التي تتجسد في تحمل الفـادي لخطيايـا

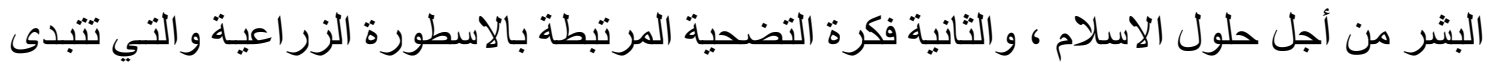
في موت تموز وبعثه من جديد (34) ).

وتتجسد تجربة السياب بـ (( معاناة شخصية مريرة مـع المرض و الغربـة و الفقر و الحاجـة

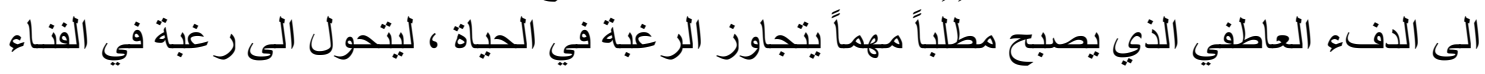

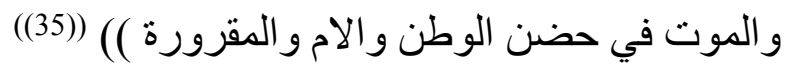

ثم يقول : هكذا عدت فاصفر لمار آني يهوذا فقد كنت سره

كأن ظلا قد اسود مني و تمثال فكرة

$$
\text { جمّدت فيه و استلّت الروح منها }
$$

خاف أن تفضح الموت في ماء عينيه

$$
\text { عيناه صخرة }
$$

راح فيها يو اري عن الناس قبره

خاف من دفئها من محال عليه فخبّر عنها

أنت أم ذاك ظلي قد أبيضّ وارفضّ نورا 
أنت من عالم الموت تسعى هو الموت مرّه

هكذا قال آباؤنا هكذا علمونا فهل كان زورا

ذالك ما ظنّ لما رآني و قالته نظرة

يشّر السياب بسوء حظه ، لانه يعيش في زمن الخيانات و الظلم و اللئام الذين يسفكون دماء

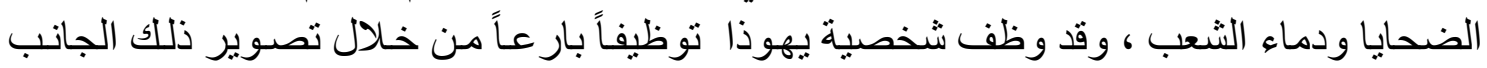

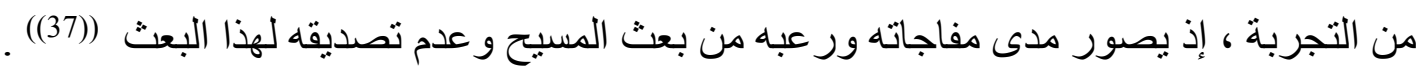
وظف شخصية يهوذا الذي هو أحد تلامذة السيد المسيح وهو الذي وشي بـه ودل الجنود

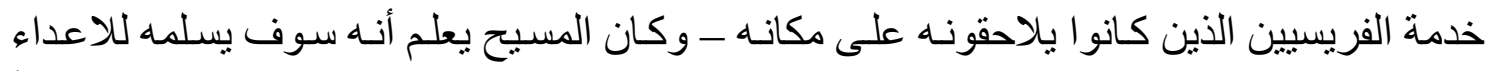

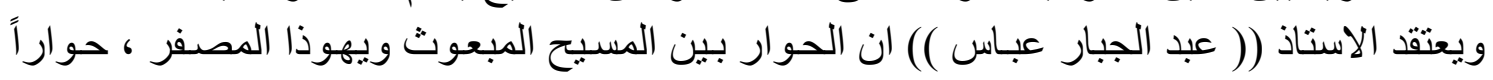
بين الثاعر وذاته وان شخصية يهوذا في القصيدة هي الوجه الاخر المذعور اندو الخائن ((38)) .

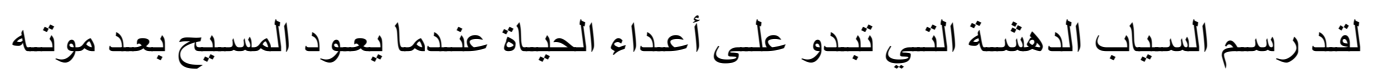

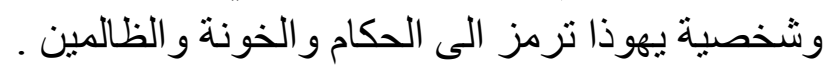

ويتمحور الحديث عند السياب حول القيامة و البعث و الازدر اء بالموت الجسدي الذي تناولـه

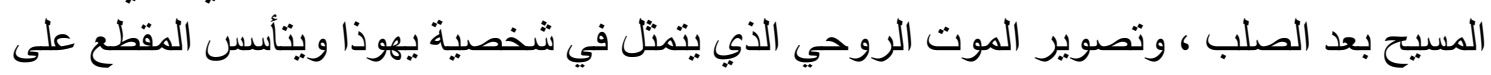

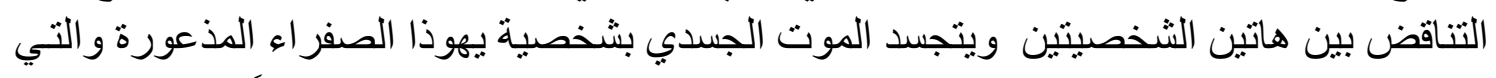

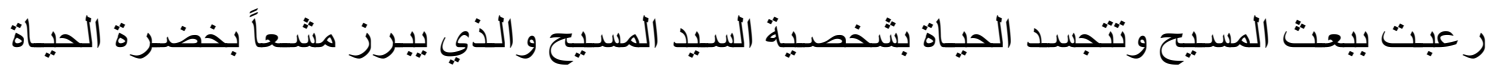
وسرمديتها وديمو متها بتضحيات المضحي و المسيح الفادي .

لقد استطاع المسيح أن (( يحيا يوم منح ذاته للاخرين ويوم مـات ليعيشو ا وكيف استحال

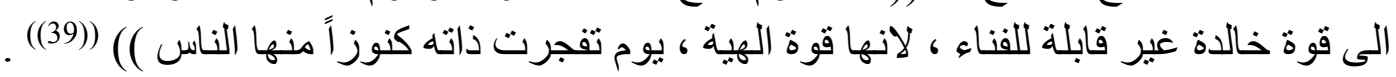

$$
\text { ثم يقول : ثدم تعدو قدم قدم }
$$

القبر يكاد بوقع خطاها ينهدم

$$
\text { أترى جاءوا من غير هم }
$$$$
\text { قدم قدم قدم }
$$

ألقيت الصخر على صدري 
أو ما صلبوني أمس فها أنا في قبري فليأتو ا إني في قبري من يدري أني من يدري ورفاق يهوذا من سيصدق ماز عموا قدم قدم

ها أنا الآن عريان في قبري المظلم كنت بالأمس ألثف كالظن كالبر عم سئري تحت أكفاني الثلج يخضل زهر الدم كنت كالظل بين الدجى و النهار ثم فجرت نفسي كنوز ا فعرّيتها كالثمار حين فصلت جيبي قماطاو كمّي دثار حين دفأت يو ما بلحمي عظام الصغار حين عريت جرحي و ضمدت حرجا سو اه حطم السور بيني و بين الإله وينتقل السياب من (( مجرد فكرة تلتف كالظن أو تتارجح (( كالظل بين الدجى و النهار ))

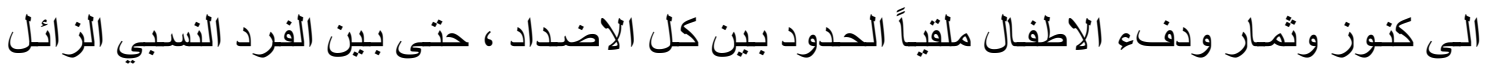

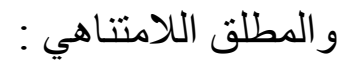

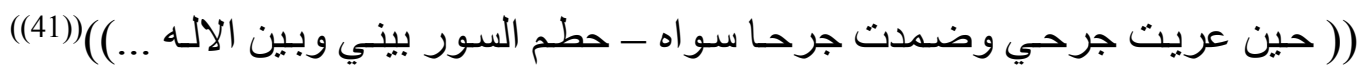

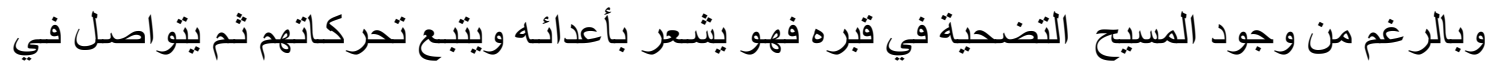

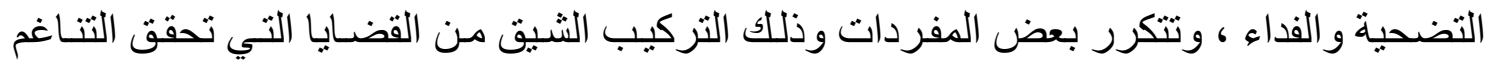

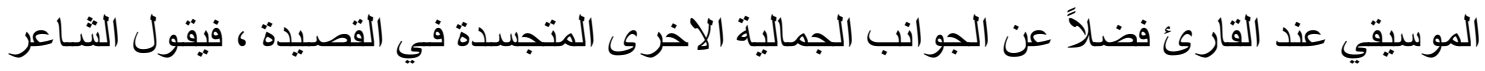

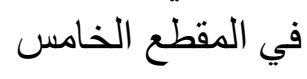
فاجأ الجند حتى جر احي و دقات قلبي 
فاجأو ا كل ما ليس موتاو إن كان في مقبرة

فاجأوني كما فاجأ النخلة المثمرة

سرب جوعى من الطير في قرية مققرة (42))

تهيمن مفاجأة الموت على كل شئ في هذا المقطع ، فالجند فاجأو اجر احه ودقات قلبه فيقول الثاعر في المقطع التالي : تلناء

$$
\text { شين البندقيات يأكلن دربي }
$$

إن تكن من حديد و نار فأحداق شعبي

من ضياء السماو ات من ذكريات و حب

تحمل العبء عني فيندى صليبي فما أصغره

ذلك الموت موتي و ما أكبره (43))

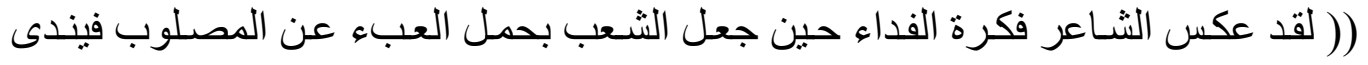

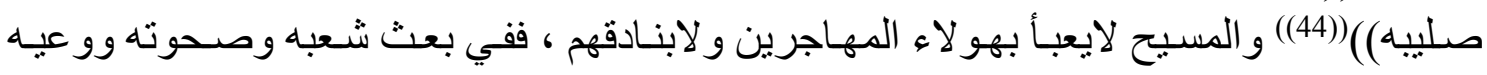
حصن منيع من كل ظلم ومن بنادق الاعداء (45)() .

ومهما يكون ظلم الطغاة مدمر اً بقو تهم وبأسهم ومهما يبلغ دعاة الخير من ضعف و واضطهاد

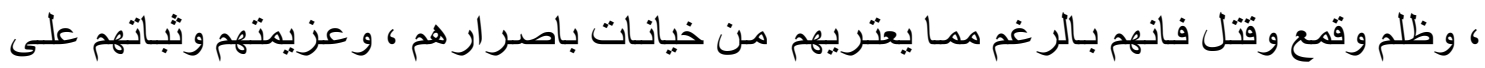
المبدأ يبلغون غاياتهم النبيلة وتحقيق أهدافهم المنشودة .

ثم في المقطع الاخير يقول الثناعر :

بعد أن سمّروني و ألقيت عينيّ نحو المدينة

كدت لا أعرف السهل و السور و المقبرة

$$
\text { كان شيء مدى ما ترى العين }
$$

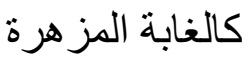

كان في كلّ مرمى صليب و أم حزينة 
هذا مخاض المدينة (46)()

يعود السياب في خاتمة القصيدة فالصلب جاء بعد التعذيب و الاضطهاد و الجوع و والايذان

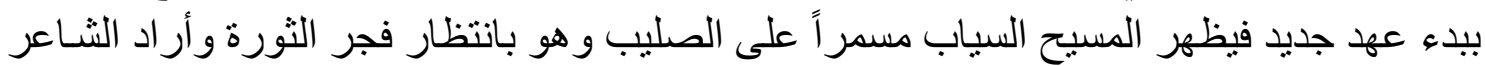

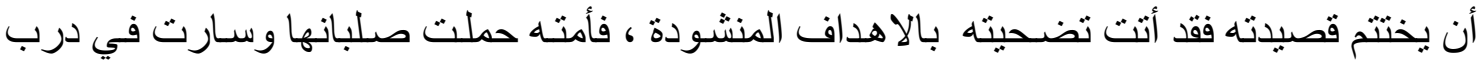

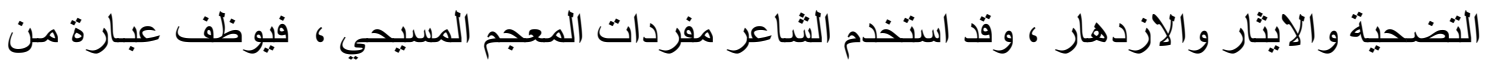

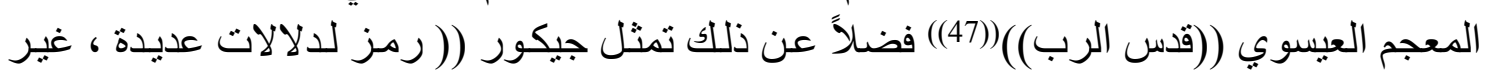

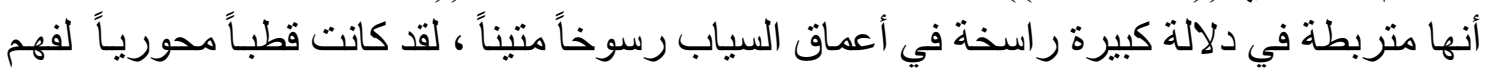

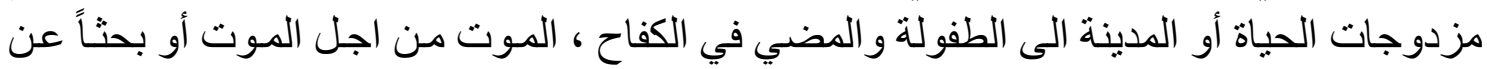

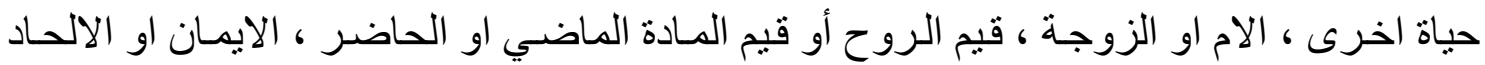

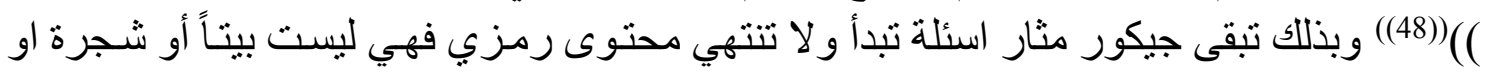

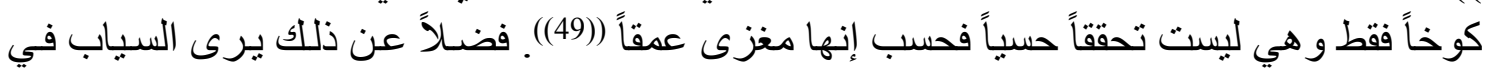

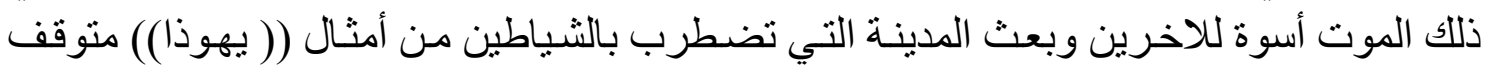

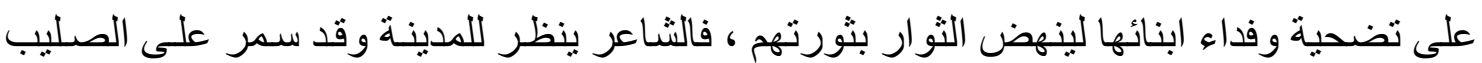

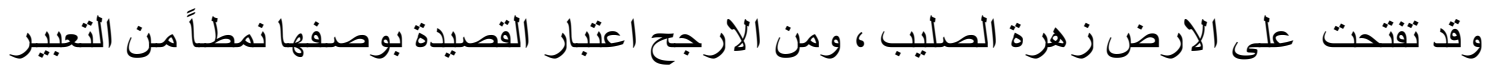

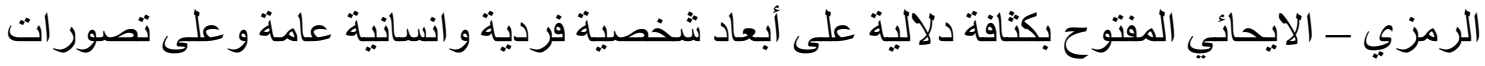

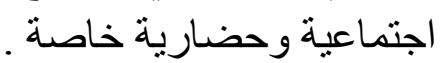

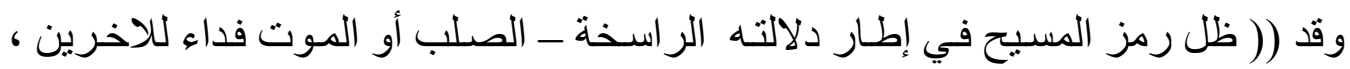

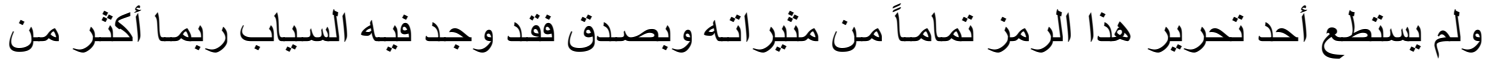

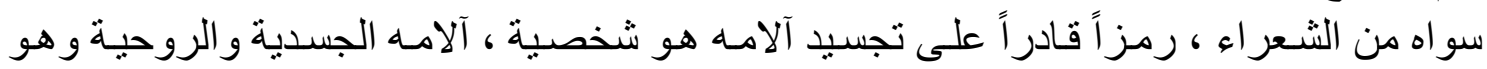

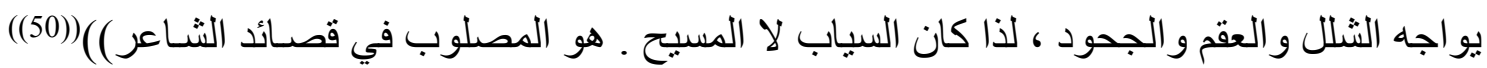

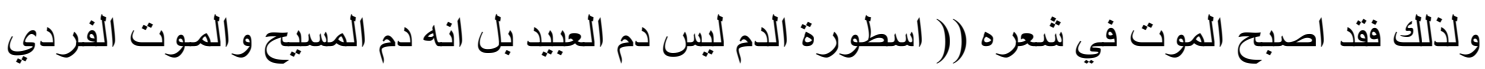

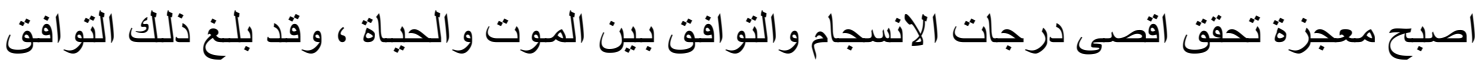

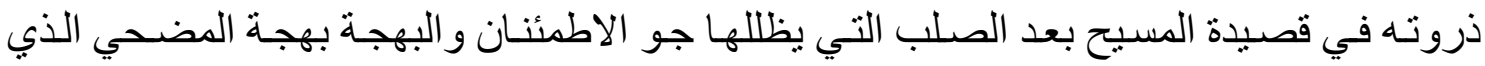

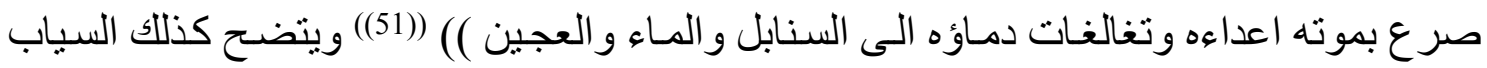

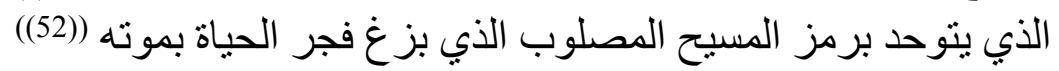

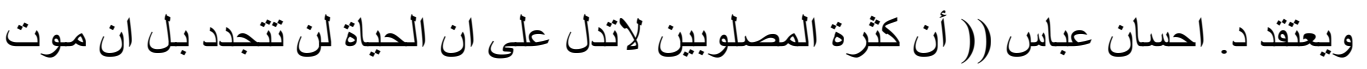

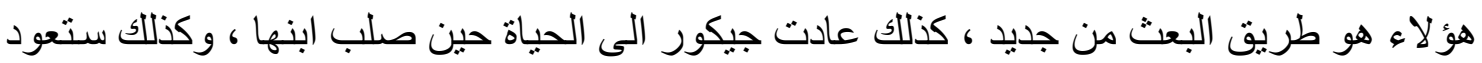

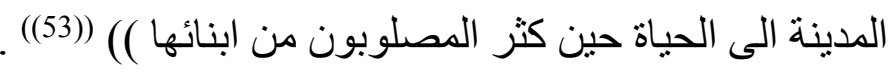


لقد استخدم السياب قصيدة القناع ((استخداماً فنياً عميقاً وشمولياً من خلال شخصيته التي

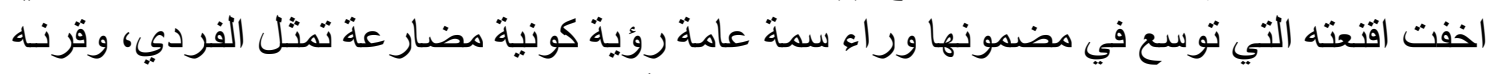

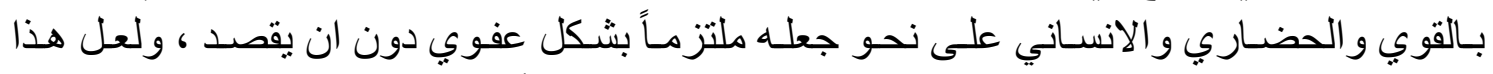

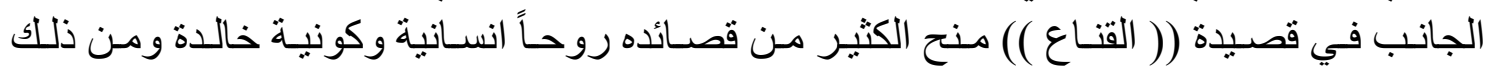

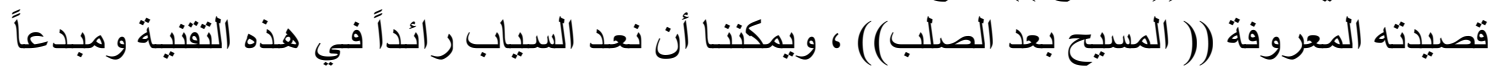

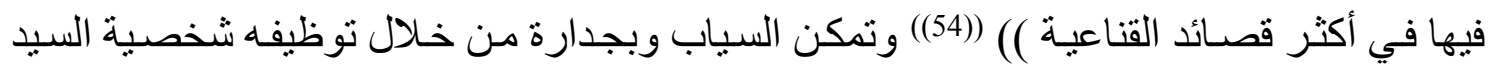

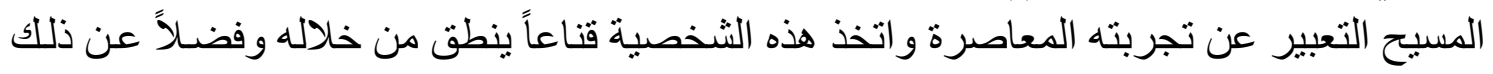

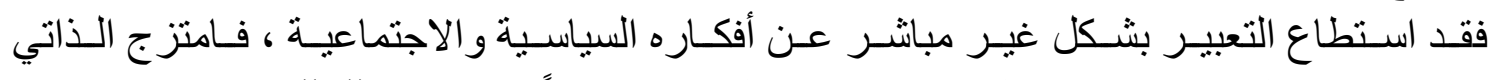
بالموضوعي الثاعر بقناعه وبذلك الصنيع ابدع السياب وجوهاً فنية جديدة (55) ).

لقد أسـهم السياب في (( تكوين وتأسيس وتمـوين منتن شـعري سـيابي خـاص في مدونـة

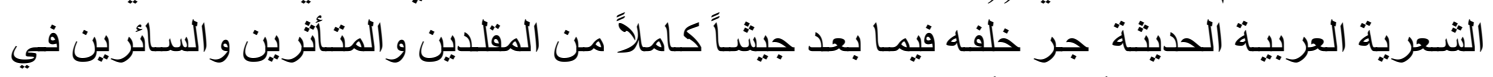

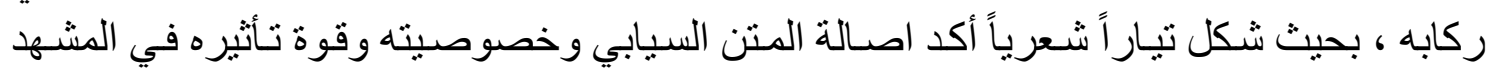

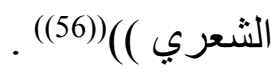

وقد برع السياب في توظيف القناع واتخـاذ المسيح قناعاً فنياً ذاتـاً وتاريخـاً ونصـاً شـعريا

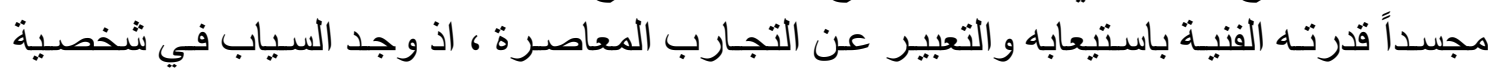

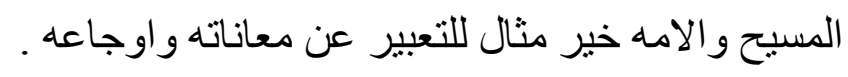

المبحث الثاني

المسيح في شعر محمود درويش

الرمز أبرز اسلوب جمالي في التعبير عن المعنى الثـري أو في رسم الصـورة في لغـة

محمود درويش فهو يوظف الرمز ويضفي عليه أبعـاداً دلاليـة شعرية جديدة يحرص فئية فيها الثـاعر

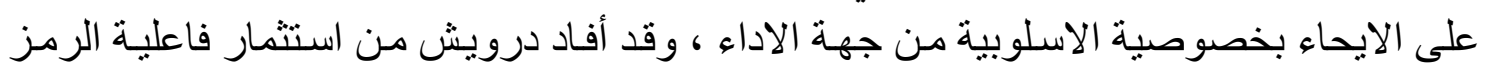

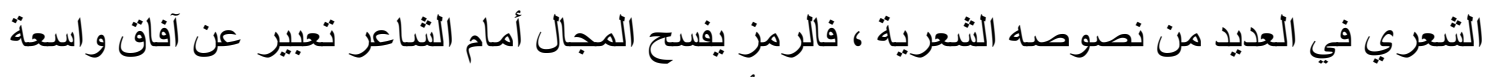

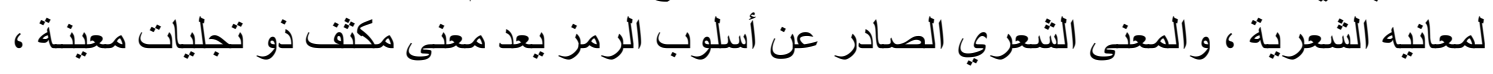

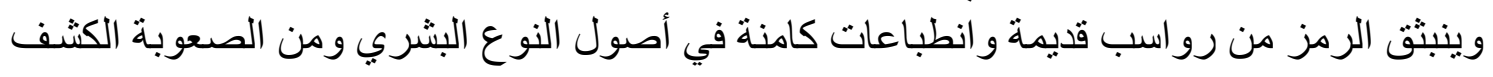

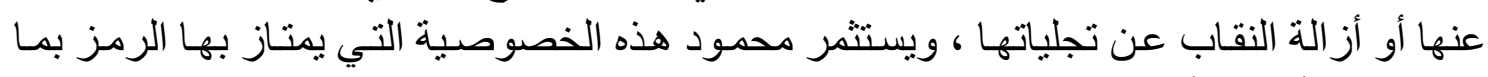

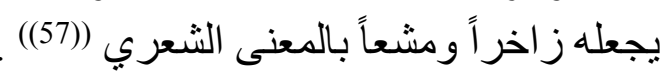

ويحدد((علي عثـري زايد))خمسـة عو امل تجذب الثـعر اء الـى استعارة الرموز التر اثيـة المختلفة . 
1. العو امـل الفنيـة : وتتمثنل باحسـاس الثـاعر بـان العودة الى التر اثل والجذور و الاستعارة

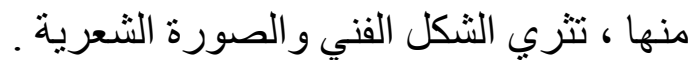

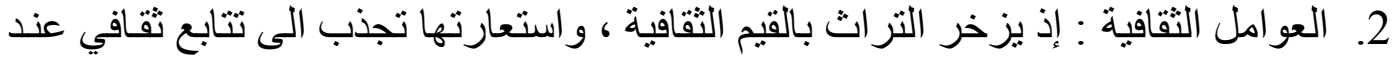
الاجيال .

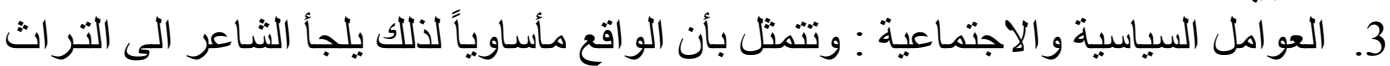

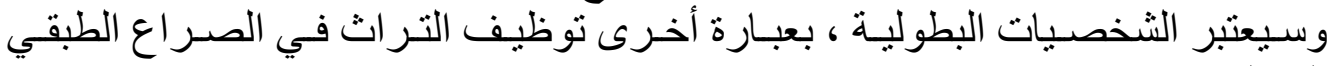

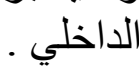
4. العو املّ القومية : حيث يعمد الثـاعر الى استثارة طاقات الامة أو الثـعب في وجـه العدو 5. العو املّ النفسية : وتتجسد بو اقع الثـاعر و اغتر ابه الروحي و المكاني ، فيلجأ الى أحضـان

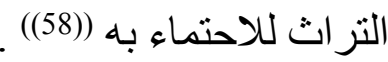
ويعتقد (( صلاح عبد الصبور )) أن عودة الاديب الى الماضي تعد (( محاولة لتكوين قثرة

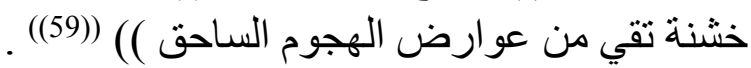
ويعتقد (( عشري زايد )) أن تأريخ العودة الى التراث و استلهام رموزه في الحيـاة الثـعرية

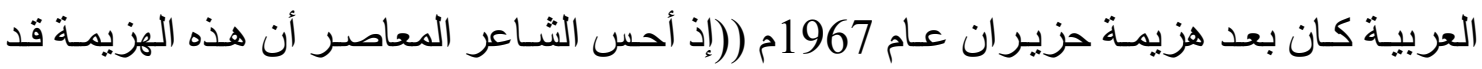

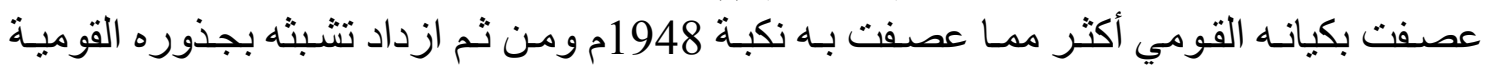

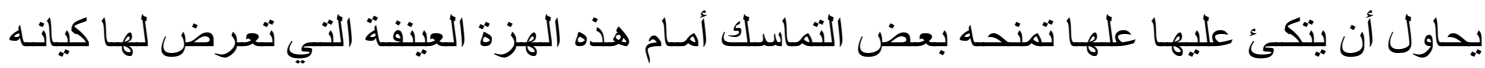

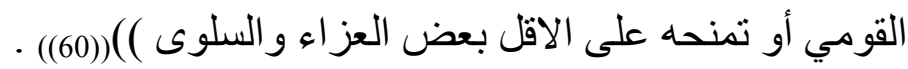

لقد أدرك محمود درويش الواقع فتعامل مع الموروث برموزه اليهودية و المسيحية و الاسلامية

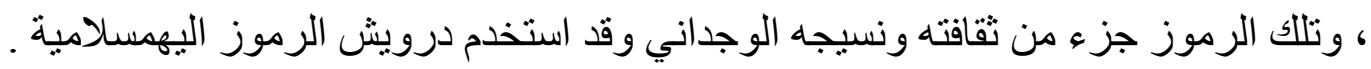

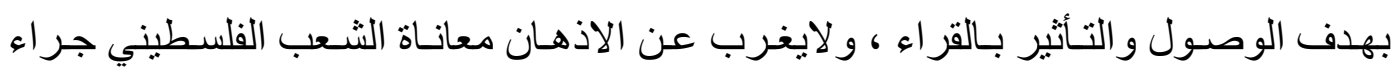

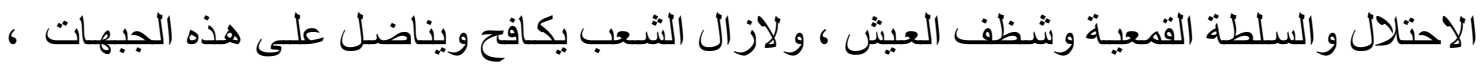
وركز درويش على استخدام الاستعار ات المتضـنة معـاني الصـمود و النضـال و الصبر و والايمـان

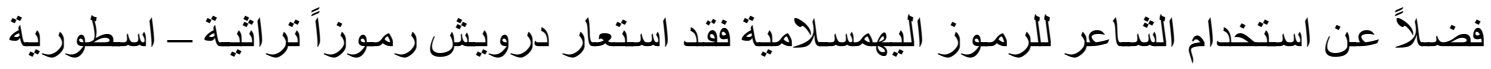
سابقة للاديان اليهمسامية وتعود للتراث البابلي والفينيقي و الكنعاني ، للتعبير عن المعاناة و النضال

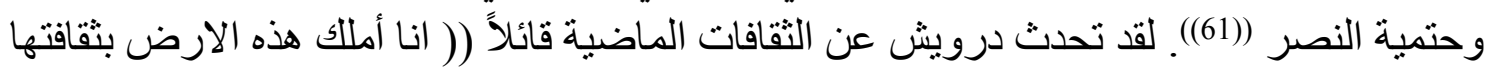

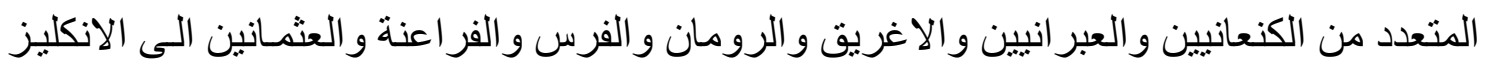

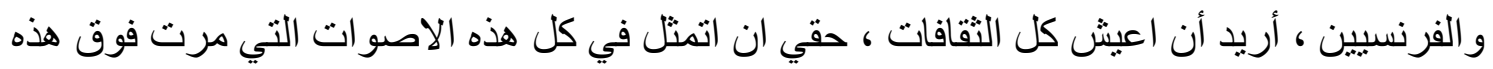

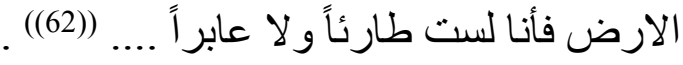

امـا الباحث (( محمد فكري )) لـه تحليل آخر حول توظيف الرموز الهيمسـلامية في شـعر

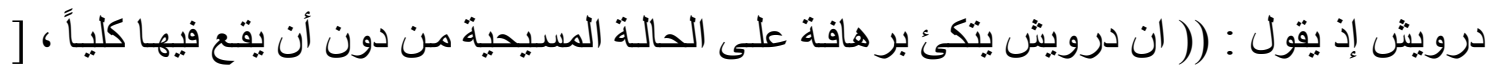


...] و هكذا يبدو ان اعتماد الرمز المسيحي الثانوي أو الجزئي يتيح للثـاعر الا يتاسـر داخل الدلالـة

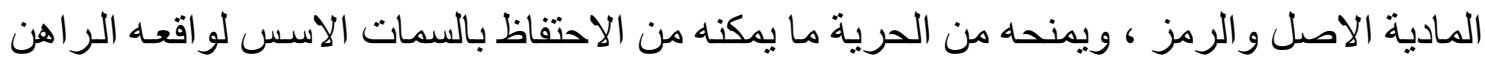
$((63)))((\ldots$

لقد تمكن درويش مـن شـرعية اسـتخدام الرمـوز التور اتيـة ، فهو يميز بين الدين اليهودي

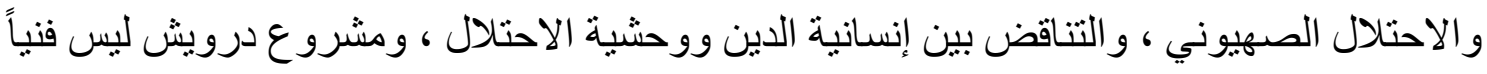

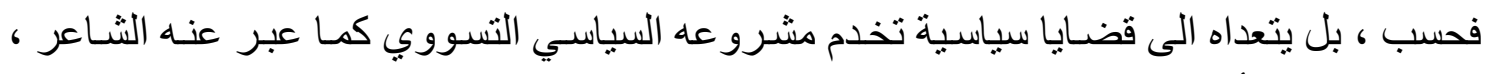

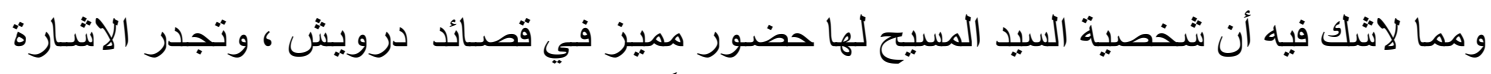

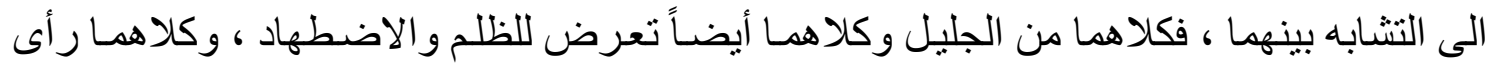

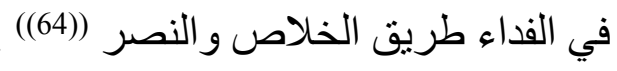

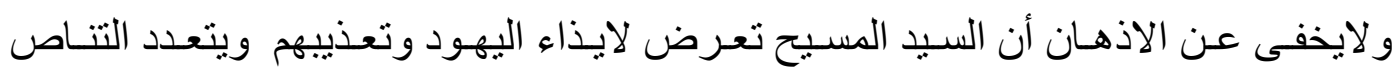

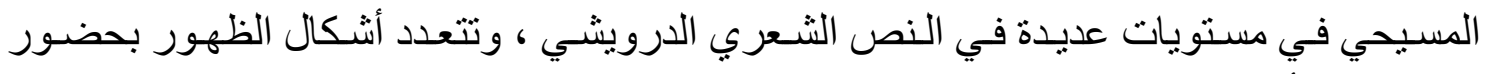

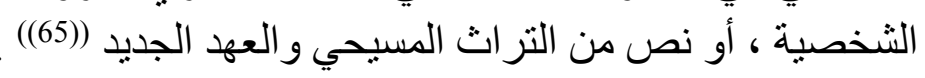

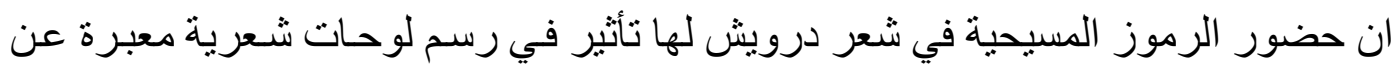

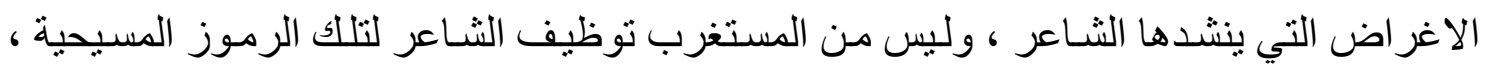

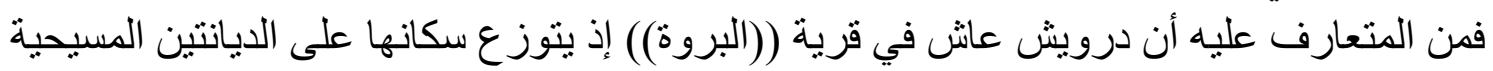
و الاسلام ، و الحياة في تلك القرى مفعمة بجميع الرموز اليهمسلامية والتي تتجسد في الحياة اليومية كالصلاة و الصوم وطقوس الوس الو لادة و الوفاة و الزواج (66)() .

و لايغرب عن الاذهان المرحلة الاولى (( الرومانسية )) في شـعر محمود درويش وقصـائده

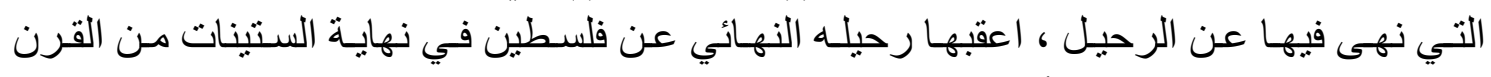

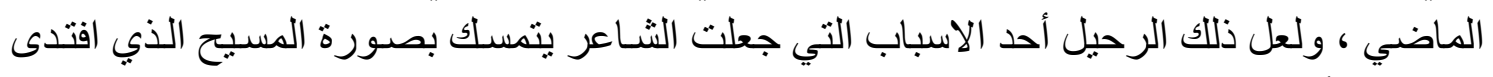

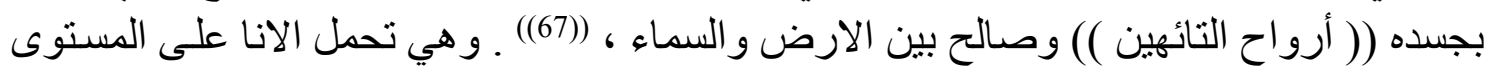

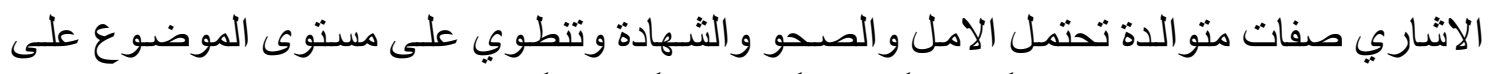

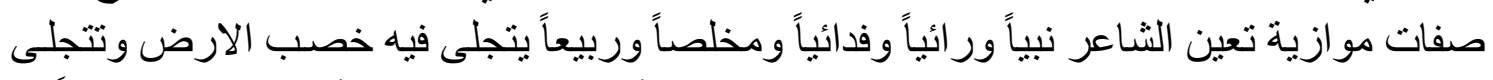

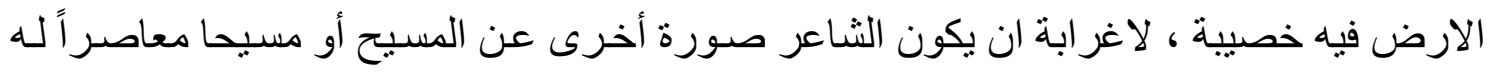

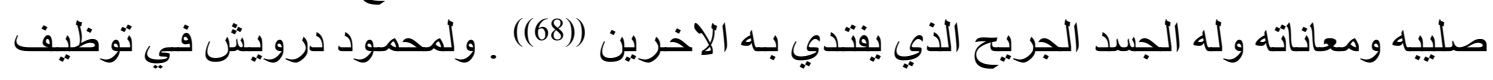

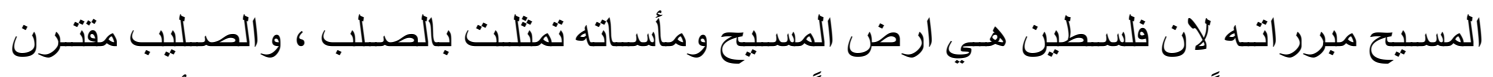

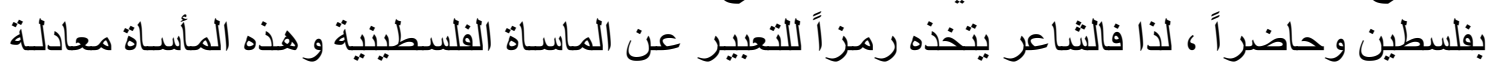

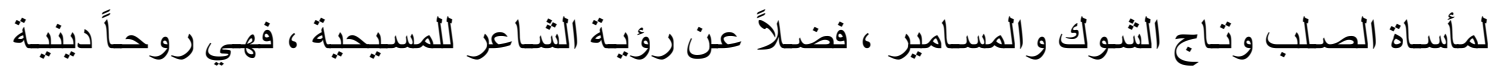

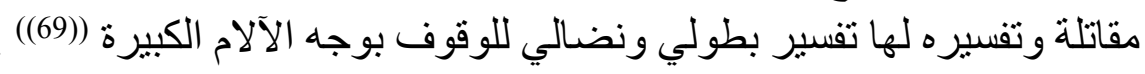




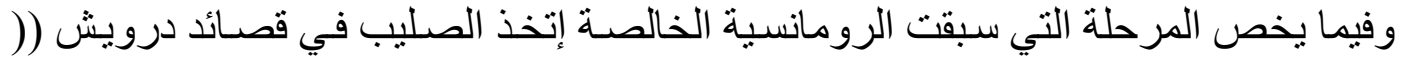

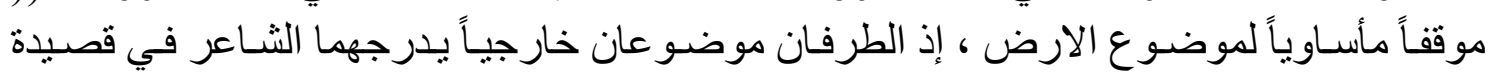

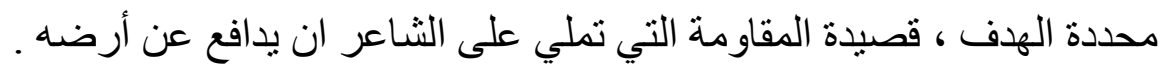

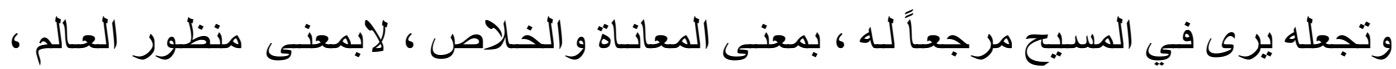

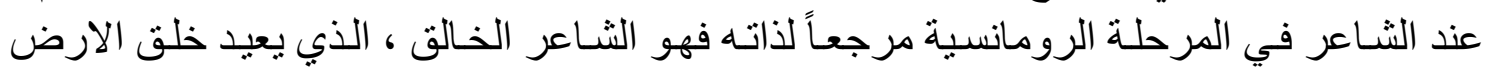

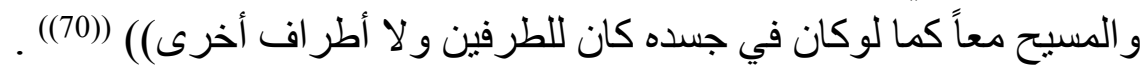

ومن الملاحظ ان المرحلة الشعرية الاولى (( الرومانسية )) عند محمود درويش وجد الثاعر

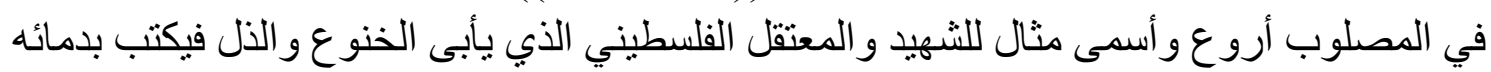
أروع معاني الحب و التضحيات ، وفي قصيدة (رو فال المغني )) يقول :

$$
\begin{aligned}
& \text { المغني على صليب الألم } \\
& \text { جرحه ساطع كنجم } \\
& \text { قال للناس حوله } \\
& \text { كلّ شيء.. سوى الندم } \\
& \text { هكذا متّ و اقفا } \\
& \text { و اقفا متّ كالثجر } \\
& \text { وكذا يصبح الصليب } \\
& \text { منبر ا.. أو عصا نغم } \\
& \text { و مساميره.. وتر ! } \\
& \text { هكذا ينزل المطر } \\
& \text { هكا يكبر الشجر ... (71)( }
\end{aligned}
$$

و المغنـي الذي يعزف بـالأوتـار يسـر الليـالي مـن أجل البقاء ومـن أجلـ ار ادة المـوت أيضـاً

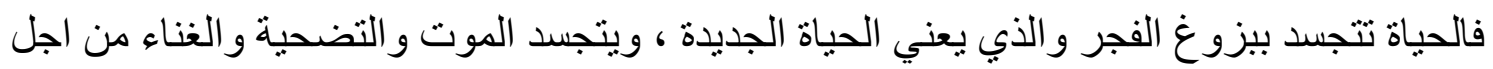

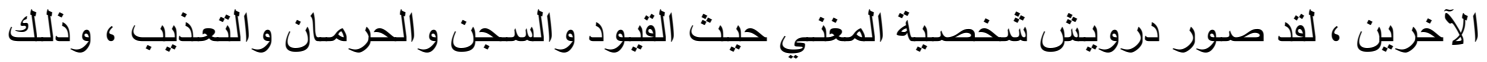


المغنـي يتــدى الاعـداء ويغنـي ويعـالج جر احـه بأوتـار العـزف التـي تـوحي بالأمـل و الطمأنينـة

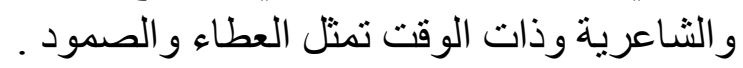

ويبرز هنا معنى الصليب فهو سبيل الفداء وطريق الخلاص الوحيد ، فالثاعر (( يعيد توليف

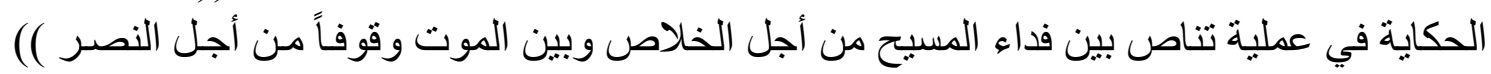

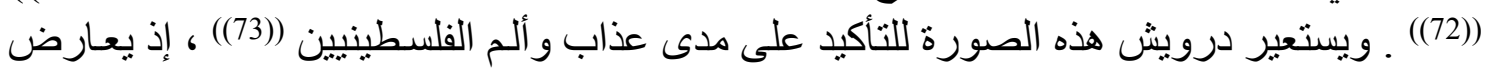

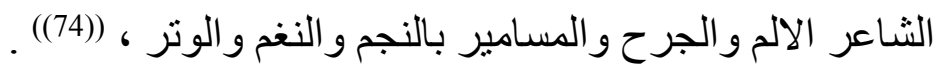

وفي قصيدته (( شهيد الأغنية )) يصور الشـاعر حواراً بينه وبين الاعداء الوحوش والطغـاة

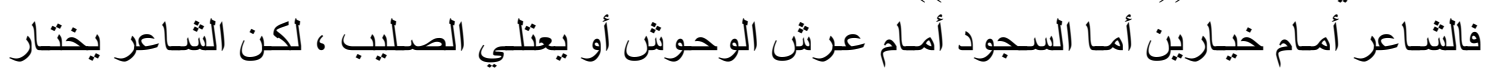

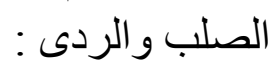

$$
\begin{aligned}
& \text { صبوا الصليب على الجدار } \\
& \text { فكّو السلاسل عن يدي. } \\
& \text { و السوط مروحة.و دقات النعال } \\
& \text { لحن يصفر : سيدي! } \\
& \text { و يقول للموتى: حذار! } \\
& \text { ــا أنت } \\
& \text { قال نباح وحش: } \\
& \text { أعطيك دربك لو سجدت } \\
& \text { أمام عرشي سجدتين! } \\
& \text { و لثمت كفي، في حياء، مرتين } \\
& \text { أو.. - - ( - } \\
& \text { تعتلي خشب الصليب } \\
& \text { شهيد أغنية.. و شمس! } \\
& \text { ما كنت أول حامل إكليل شوك }
\end{aligned}
$$




$$
\begin{aligned}
& \text { لأقول للسمر اء: إبكي! } \\
& \text { يا من أحبك، مثل إيماني ، } \\
& \text { و لاسمك في فمي المغموس } \\
& \text { بالعطش المعفر بالغبار } \\
& \text { طعم النبيذ إذا تعتق في الجرار! } \\
& \text { ما كنت أول حامل إكليل شوك } \\
& \text { لأقول: إبكي! } \\
& \text { فعسى صليبي صهوة، } \\
& \text { و الثوك فوق جبيني المنقوش }
\end{aligned}
$$

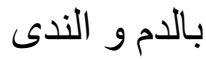

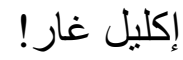

$$
\begin{aligned}
& \text { و عساي آخر من يقول: } \\
& \text { أنا تشهيت الردى! (75)) }
\end{aligned}
$$

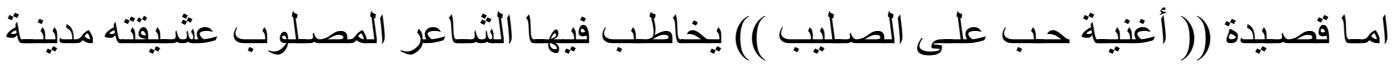
القدس ، ودلالة الصليب في القصيدة معبرة عن محبة أزلية ورسالة سلام سرمدية وبشارة للانسانية الئية

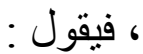

$$
\begin{aligned}
& \text { وكوني ' كما شئتب , بُرْج حمامْ } \\
& \text { إذا ذوَّبتني يداك } \\
& \text { ملأت الصحارى غمام } \\
& \text { لحبك يأكل حبي , مذاق الزبيبْ }
\end{aligned}
$$

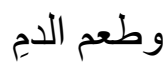

$$
\begin{aligned}
& \text { على جبهتي قمر لا يغيب }
\end{aligned}
$$




$$
\begin{aligned}
& \text { ونارٌ وقيثارة في فمي! } \\
& \text { إذا متُّ حباً فلا تدفنيني } \\
& \text { وخلي ضريحي رموش الرياح } \\
& \text { لأزرع صوتلك في كل طين } \\
& \text { وأشهر سيفلك في كل ساح } \\
& \text { أحبك , كوني صليبي } \\
& \text { وماشنئت كوني } \\
& \text { وكالثمس ذوبي } \\
& \text { بقلب.. و لا ترحميني ...(76)() } \\
& \text { وفي قصيدة (( صوت من الغابـة )) يغدو الصـود الى الصليب الخيـار الامثل الذي يمنح } \\
& \text { الوجود الفلسطيني معناه فيقول : } \\
& \text { من غابة الزيتون }
\end{aligned}
$$

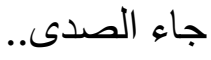

$$
\begin{aligned}
& \text { و كنت مصلوباً على النار ! } \\
& \text { أقول للغربان: ل ال تنهثي } \\
& \text { فربما أرجع للارار } \\
& \text { و ربما تشتي السما } \\
& \text { ربما } \\
& \text { تطفيء هذا الخشب الضـاري! } \\
& \text { أنزل يوماً عن صليبي }
\end{aligned}
$$

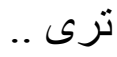


كيف أعود حافياً .. عاري !؟ (77)) وفي ديوان (( عاثتق من فلسطين )) وفي قصيدته (( صوت وسوط )) حيث تتسع مسـاحة

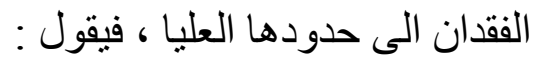

$$
\begin{aligned}
& \text { لو كان لي قدم ، } \\
& \text { مشيتُ.. مشيت حتى الموت } \\
& \text { من غاب لغاب... }
\end{aligned}
$$

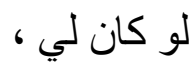

$$
\begin{aligned}
& \text { حتى صليبي ليس لي } \\
& \text { إنّي له } 6 \\
& \text { حتى العذاب! (78)() }
\end{aligned}
$$

ويخيل للشاعر ان صليب بلاده سيحرق يوماً ويغدو ذكرى وذلك في قصبدة((صلاة اخيرة)):

$$
\begin{aligned}
& \text { يخيل لي يا صليب بلادي } \\
& \text { ستحرق يوما } \\
& \text { و تصبح ذكرى ووشما } \\
& \text { وحين سينزل عنك رمادي } \\
& \text { ستضحك عين القدر } \\
& \text { و تغمز: ماتا معا (79)() }
\end{aligned}
$$

ويرسم درويش صورة أخرى للصليب ، فهو يحمل أحزان الأرض ومآسيها ليخدو صليباً

$$
\text { بكبر الثهداء ، فيقول في قصبيدته (( الى ضائعة )) : }
$$

$$
\text { اذا مرت على وجهي }
$$

أنامل شعرك المبتل بالرمل

$$
\text { سأنهي لعبتي.. أنهي }
$$


و أمضي نحو منزلنا القيم على خطى أهلي و أهتف با حجارة بيتنا, صلّى! إذا سقطت على عيني سحابة دمعة كانت تلف عيونلك السوداء سأحمل كل ما في الأرض من حزن صليبا يكبر الثهداء عليه و تصغر الدنيا و يسقي دمع عينيك رمال قصائد الأطفال و الثعر اء! (80)( وفي قصيدة (( قاع المدينة)) فصليب مدينتهم علمهم لون القرنفل و البطولة وهو الجسر

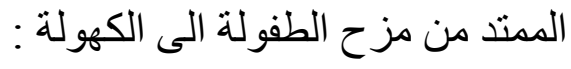
شكر ا_ صليب مدينتي شكرا لقد علّمتنا لون القرنفل و البطولة يا جسرنا الممتدّ من فرح الطفولة يا صليب_ إلى الكهولة

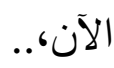
نكتشف المدينة فيك

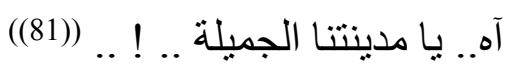
ونزوله في قصيدة (( مرة أخرى )) يصور الثاعر نزولهه من الصليب هو و الثهـداء فلم يعثر منهم أحد على ارض ولم فيدة (ليصروا اسماء : 


$$
\begin{aligned}
& \text { مرّة أخرى } \\
& \text { يفر الثهداء } \\
& \text { من أغاني الثعر اء } \\
& \text { مرة أخرى } \\
& \text { نزلنا عن صليبينا } \\
& \text { فلم نعثر على أرض } \\
& \text { ولم نبصر سماء } \\
& \text { حذف الظلّ يديها من جبيني } \\
& \text { فاختبأنا في الظهيره ((82)) }
\end{aligned}
$$

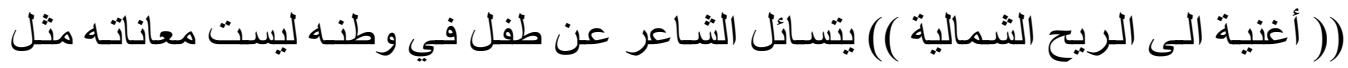

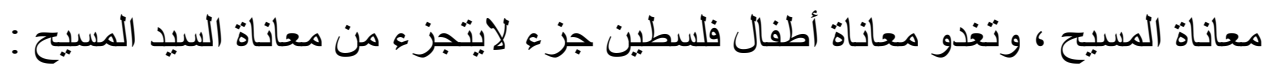
بيني وبين البر هة امتدَّت عصور

$$
\text { بالقبد أحلم، }
$$

كيف يدخل وجه يافا في حقيبهُ..! قُبلُ مجفّفة على المنديل من دار بعيدهُ.

ونو افذ في الريح، ياريح الثمان ردّي إلى الأحباب قُبلتهم و لا تأتي إلّىى! من يشتري صدر المسيح (83)) 
وفي قصيدة (( نشيد الرجال )) ترد استعارة صورية أخرى فيقول :

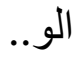

أريد المسيح

نعم! من أنت ؟

أنا أحكي من" إسر ائيل" - أن

و في قدمي مسامير... و إكليل

من الأشو الك أحمله

أأكفر بالخلاص الحلو

أم أمشي و احتضر ؟ (84)()

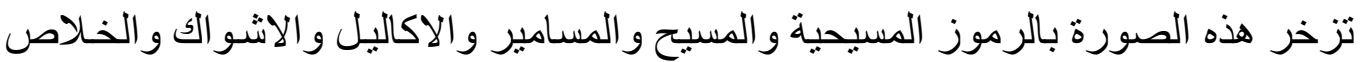

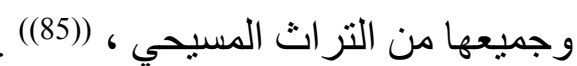

بعد سقوط القس ((1967))م يغدو للصليب معنى آخر هو المحبة و العطاء و السلام .

وفي قصيدته الارض التي كتبها درويش عام 1976 م ابدع درويش في هذه القصيدة رمز تكوينياً

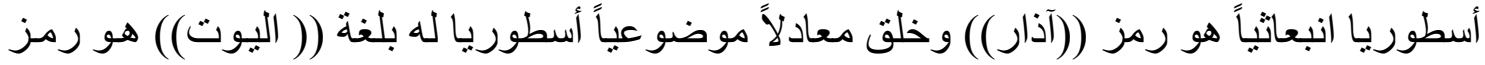

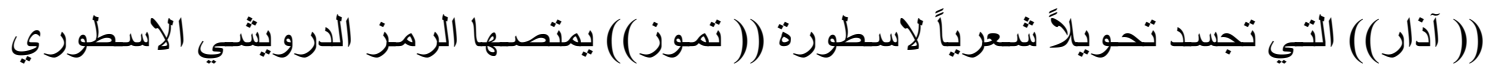

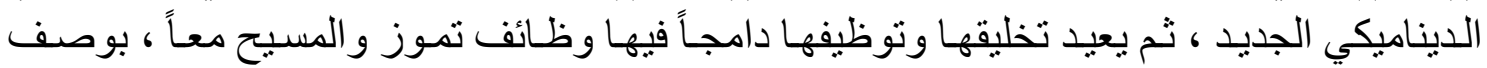

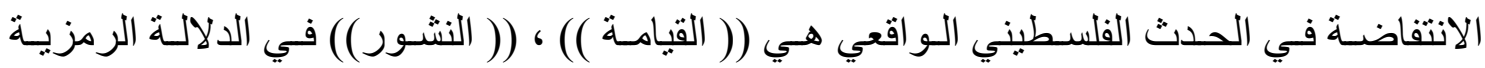

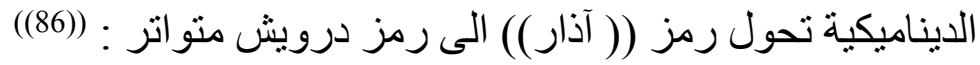
كأنّ الهياكل تستفسر الان عن أنبياء فلسطين في بدئها المتو اصل هذا اخضر ار المدى واحمرار الحجارة-

هذا نشيدي

وهذا خروج المسيح من الجرح والريح أخضر مثل البنات يغطي مساميرة وقيودي 
وهذا صعود الفتى العربيّ الى الحلم و القد....(87)( استطاع درويش هنا ان يحرر قصيدة الغزل التقليدي من أحادية المعنى و أدر اج ضمنها قيم المقاومة

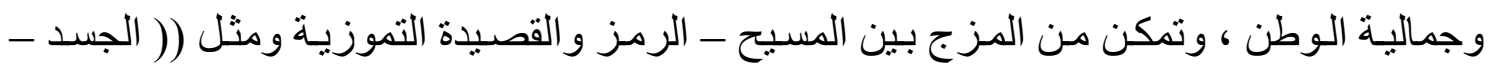

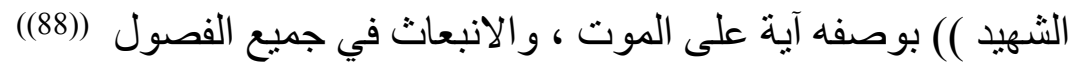

وتثنير الانتفاضة في مرجع الواقع الى القيامة في البعد الدلالي القيومي ف (( تموز و المسيح

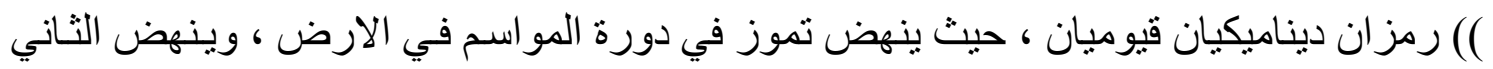

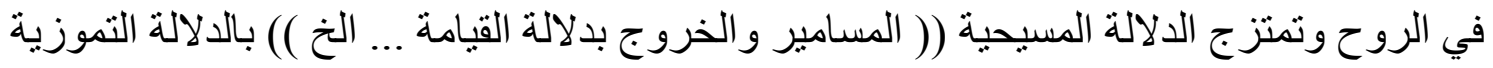

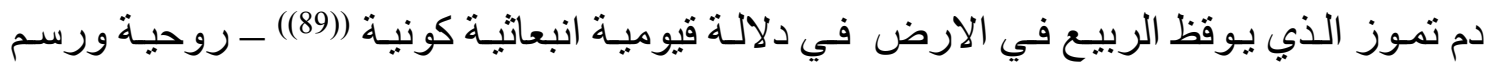
درويش لوحات شعرية متعددة مشعة بالاخضر ار وللايقاع اللوني دور اً مهماً في الايقاع التكويني

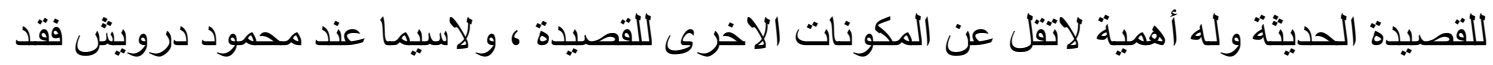

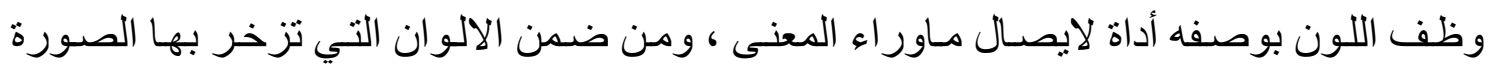

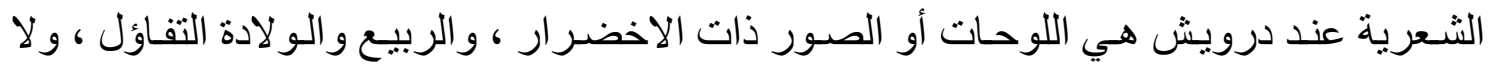

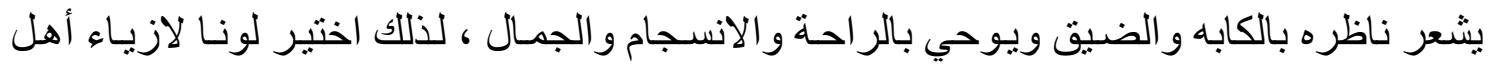

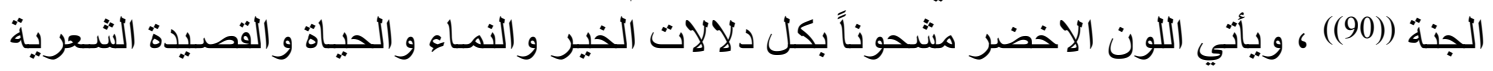

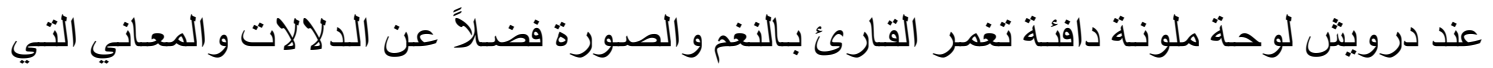

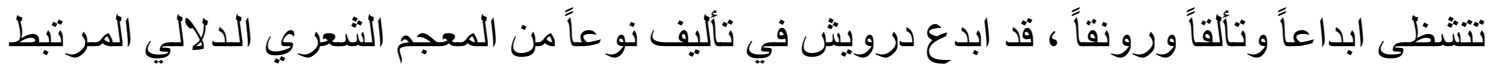
برمز الارض مثل : الاستيقاظ ، اخضر ار المدى خروج المسيح أخضر كالنبات ، الربيع النهائي ،

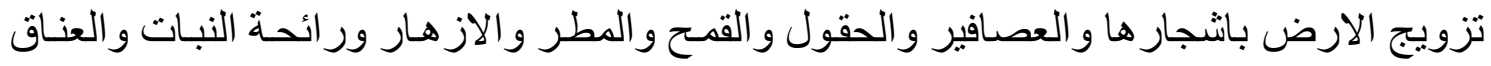

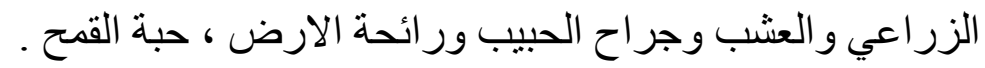

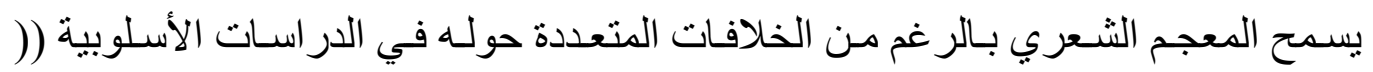
باكتشاف المثال الجمالي المتعددة حوله في الدر اسات الأسلوبية باكتشاف المثال الجمالي الذي يحكم

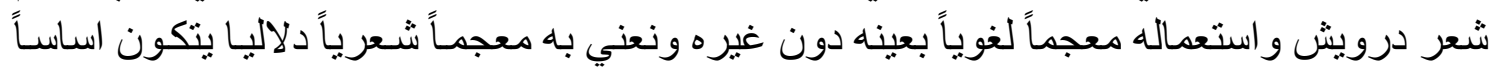
من الرموز الكلية الديناميكية . دورئية

يمكن تحديد هذا المثنال بـ((المثال الجمـالي التمـوزي)) الذي يرتد اليـه مـايمكن ان نصفهـ بـ((المعجم الثعري الدلالي)) إذ يحكم في المنظور الدلالي عملية اختيار المفردات في عملية الخلق

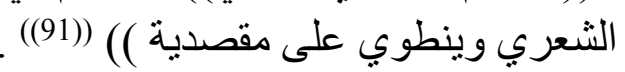

وتتهال عملية التوليف الثعري بغز ارة على الثـاعر في قصيدته (( مديح الظل العالي ))

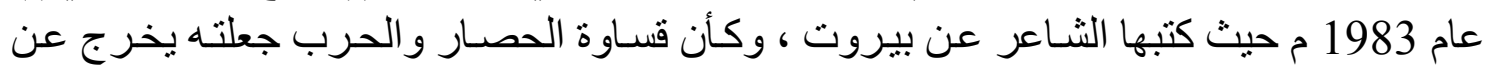


طوره فيغدو التأليف كأنه وحي ينزل من السماء وذلك بتوليف قر آني من سورة العلق و انجيلي عن المسيح الفادي ، فيقول : إنجيلُ أعدائي ونور اةُ الوصـايا البائسهُ ان الطلب مجاللك الحيوي مسر الك الوحيد من الحصار الى الحصار ومن أدمى جبين الله يا.. الله سماه وانزله كتاباً او غماماً (93))

(( إذ يتحـول صـوت المسيح مـن الـدعوة الـى التسـامح و الصـبر على العذاب الـى الدعوة للنضال و الثورة ـ ان هذه الرموز ليست إلا نو عاً من الاحتيـال الفني مارسـه الثـاعر ليعـايش و اقعـاً

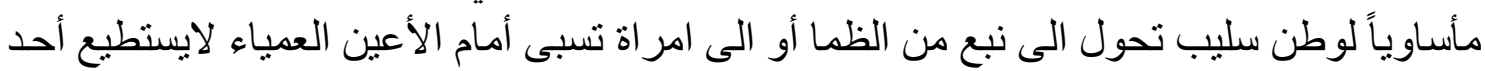

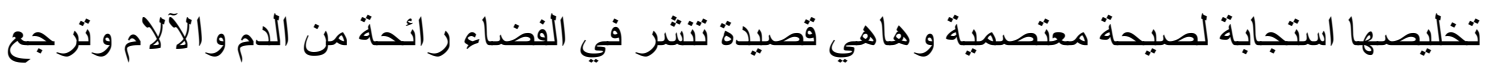

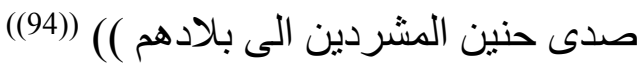

أما في قصيدة (( مأساة النرجس وملهاة الفضة )) يقول الثاعر في المقطع الخامس : حجر يشع غموضاً ، اقصى الوضوح هو الغموض فكيف ندرك ما نسينا ! عاد المسيح الى العشاء ، كما تثاء ومريم عادت اليه على جديلتها الطويلة كي تغطي مسر ح الرومان فينا هل كان في الزيتون ما يكفي من المعنى .. لنملأ راحيته سكينة وجروحه حبقاً وندلق روحنا الفاعية ((95))

أنها العودة لتأويل الماضي بجروح الوضع الر اهن و العودة لقر اءة الر اهن بعين تاريخ يعيد

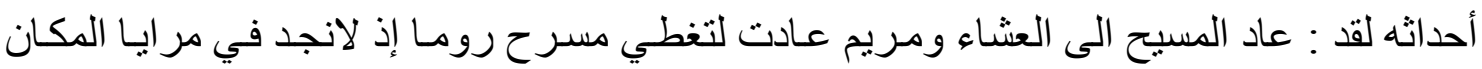

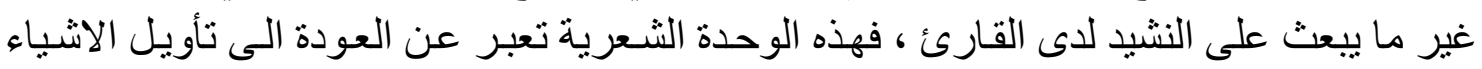

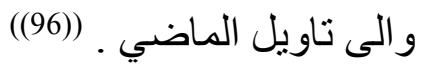
فضلاً عن ذلك فإن درويش لم يعد الثعر يوظف الدين والاسطورة بوصفها قالبـاً استعاريا

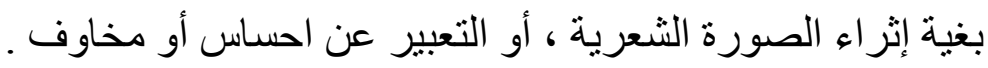


فهو يعتقد ان توظيف التاريخ و الدين و الاسطورة أصبح جزءاً من الرؤية والنبو ءة الثـعرية

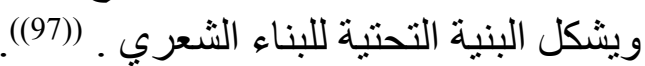

وفي ديو انـه الحسادي والعشرين (( لاتعتذر عما فعلت )) يتغنسى الثـاعر للمستقبل العصي

على الولادة ((ويقز برشاقة على جو اد الامل مما يثي بعنفوان الثباب الابداعي ، حتى كأنه ايقونة الانة الروح العربي الجموح في إصر اره على رسم جداريـة الفن وهو في قلب الحصـار لتكون معادلاًا

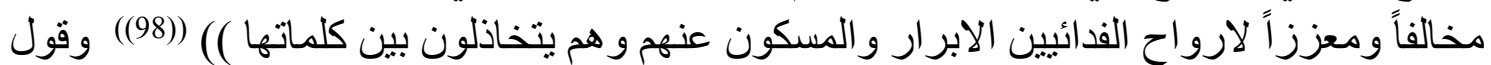
في قصيدته عن القدس بوصفها حلم جسيم مفعم بالنور و المحبة : في القدس، أَعني داخلَ السُّرر القديمه، أَسيرُ من زَمَنٍ إلى زَمَنٍ بلا ذكرى تُصوِّبُني. فإن الأنبياءَ هنالك يقتسمون تاريخَ المقدَّس... يصعدون إلى السماء ويرجعون أَقََّّ إحباطاً وحزناً، فالمحبَّةُ و السـام مُقَََََّان وقادمان إلى المدينة. (99)( ويسير الثاعر في نومه خفيفاً لايرى أحداً ، حتى يصبح غيره في التجلي : أَمشي كأنّي و احدٌ غْيرِي. وجُرْحِي وَرْدَةُ بيضاءُ إنجيليَّةُ. ويدايَ مثل حمامنَّنْ على الصليب تُحلِّقان وتحملان الأرضَ. لا أمشي، أَطيرُ، أَصيرُ غَيْري في التجلّي. لا مكانَ و لا زمان ـ فمن أَنا؟ أَنا لا أنا في حضرة المعر اج. لكنّي أُفكِرْر : وَحْدَهُ، كان النبيّ محمِّدُ يتكلِّمُ العربيَّةَ الفُصنحَى. ((وماذا بعد؟)) 


\author{
ماذا بعد؟ صاحت فجأة جنديّة:ٌ

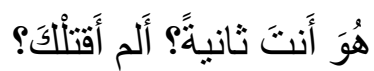 \\ قلت: قَتَلْنتي... ونسيثُ، مثلاك، أن أَموت. (100)()
}

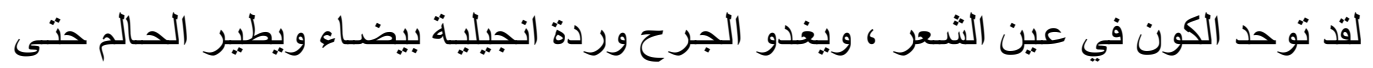

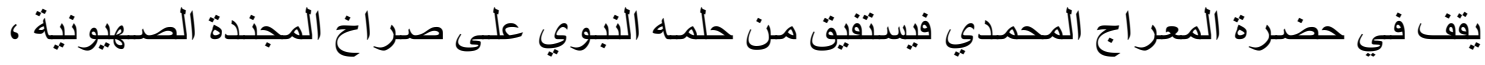

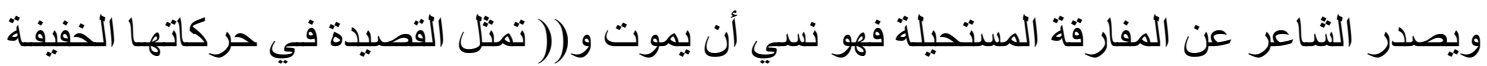

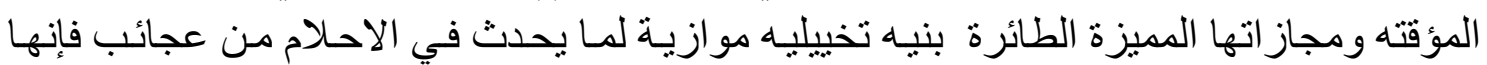

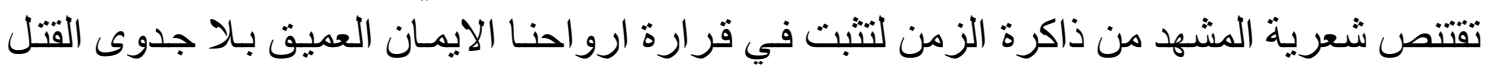

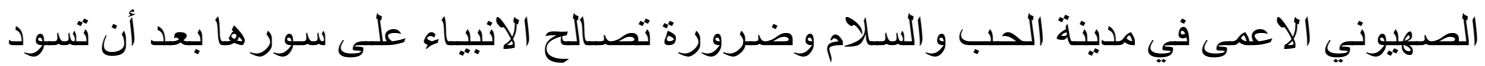

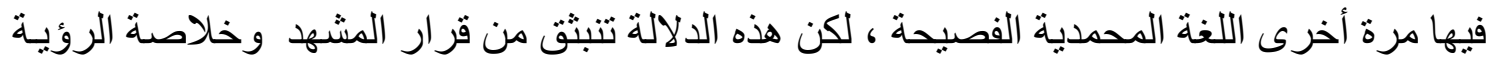

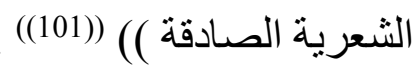

ان محمود درويش في تجربته الثعرية وهي تجرية المأسـاة الفلسطينية كونها باعثه الاول

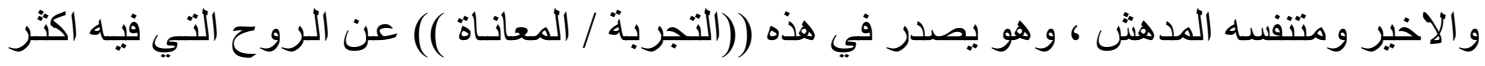

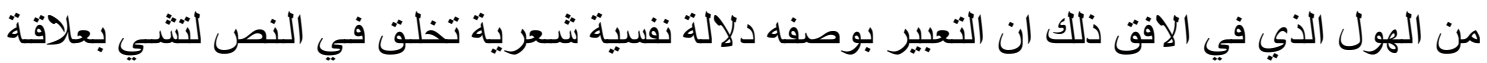

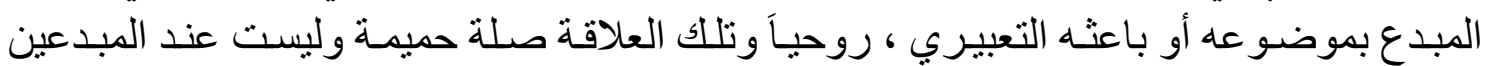

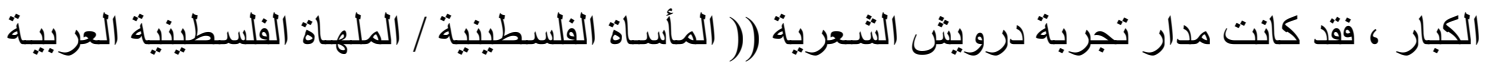

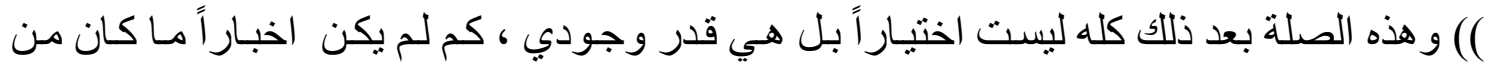

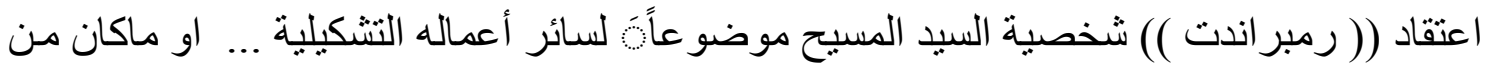

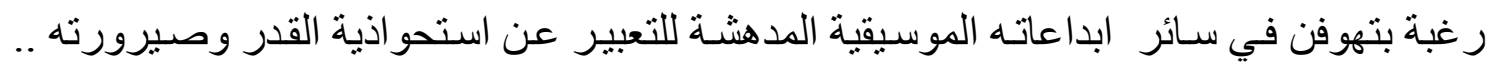

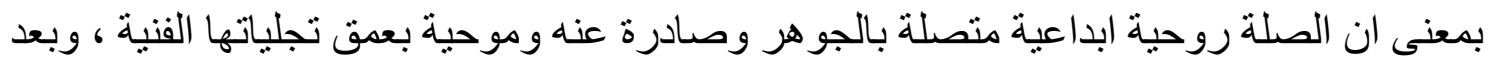

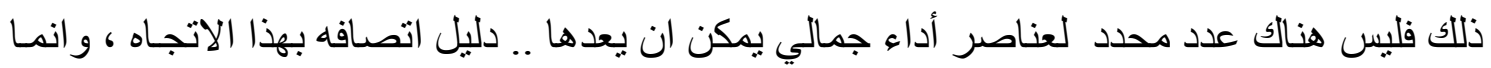
هو أفق ابداعي مفتوح لتجليات الحداثة ومديات التجديد وهاجس النزوع الروحي المتصف بالحيوية

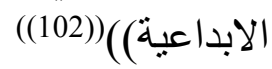

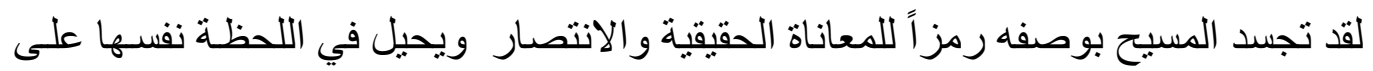

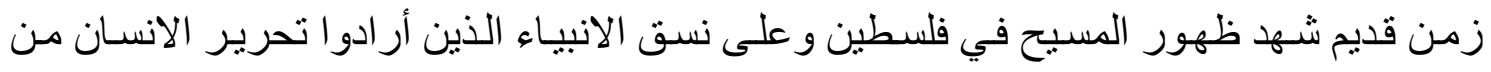
العبودية وتحرير الارض من الدنس و الرذائل ويستدعي رمز المسيح قيم البطولة و الفداء و الفضيلة

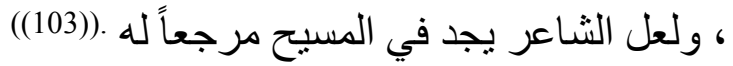




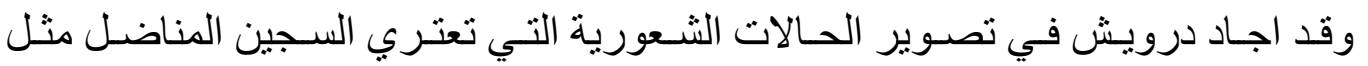

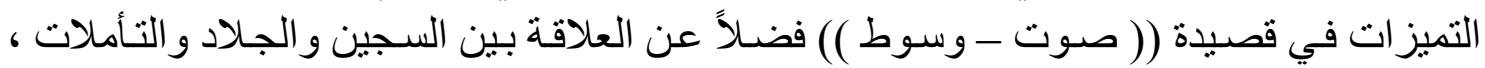
وتصوير العذاب النفسي و الجسدي و علاقة التناقص و الصر اع بين الخير و الثـر فالصليب و أكاليل

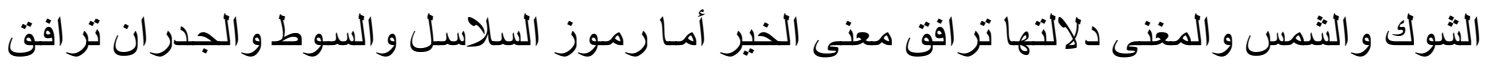
دلالتها الثر ، وصورة الاعداء كما يلاحظ في قصيدة (( قال المغني )) (104)).

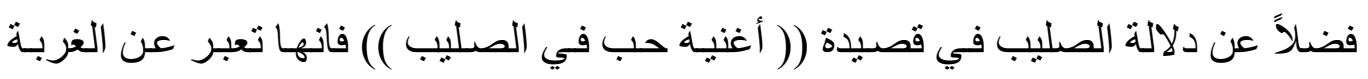

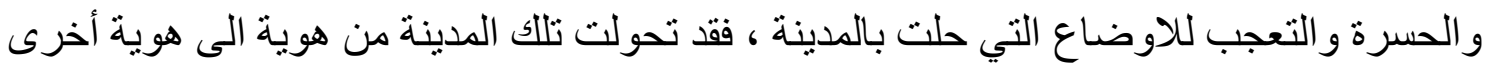
وذلك التحول نتيجة حتمية ومفروضة بقوة مادية وبشرية (105)) .

في قصيدة (( القربان )) وظف الثاعر شخصية المسيح ، وتتألف القصيدة من خمسة عثرة وحدة

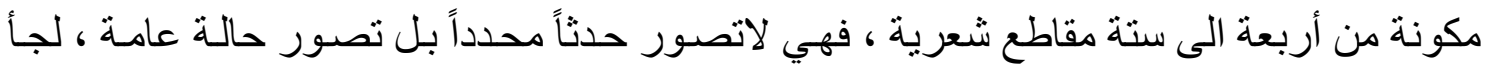

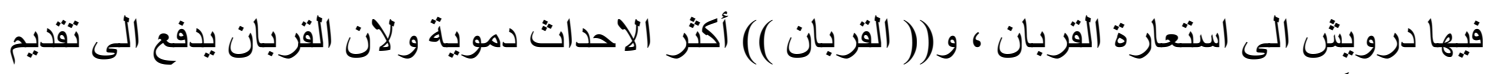

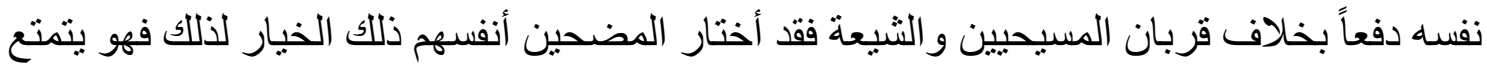

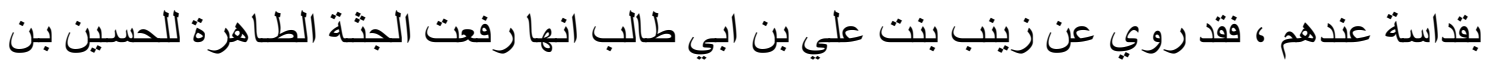

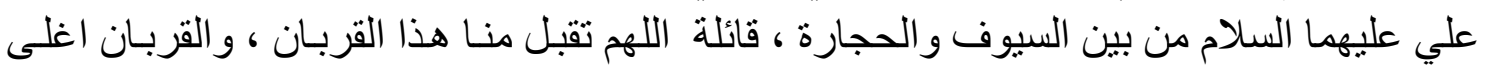

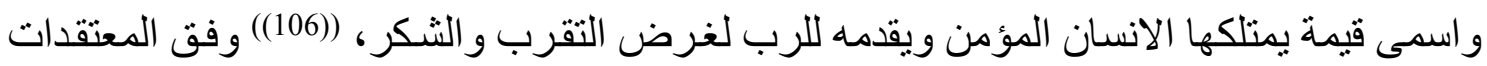

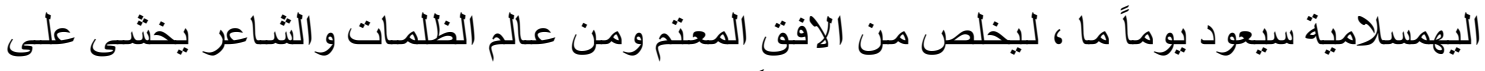

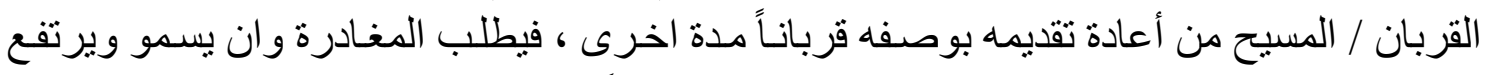
فوق نجم الثريا ويستقي الثاعر من آيات الذكر الحكيم قائلاً :

فأي آلاء نكذب؟ من يطهرنا سوالك؟ وقد ولدت نيابة عنا هناكل. ولدت من نور ونار.. وكنا نحن نجارين مو هوبين في صنع الصليب فخذ صليبك وأرتفع فوق الثريا ((107)) 
ثم يقدم الثاعر مقطعاً شعرياً آخر ينطوي على تساؤل ، فكم من مرة ستعود حياً ؟ فالقربـان

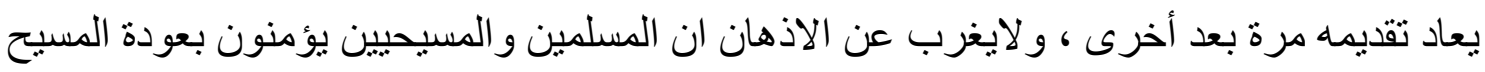

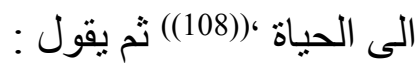

$$
\text { سنقول: لم تخطئ، ولم }
$$

نخطئ..

إذا لم يهطل المطر أنتظرناه،

$$
\text { وضحينا.. }
$$

بجسك مرة أخرى.

فلا قربان غيرك.. يا حبيب الله..

با أبن شقائق النعمان

كم من مرة ستعود حيا!

كن همزة الوصل الخفيفة بين

آلهة السماء وبيننا

قد تمطر السحب العقيمة من

$$
\text { نو افذ حرفلك العالي }
$$

وكن نور البشارة

و اكتب الرؤيا على باب الدغارة

$$
\text { و أهدنا دربا سويا }
$$

وليحتفل بك كل من يخضر

$$
\text { من شجر ومن.. حجر }
$$

ومن أثنياء تنساها الفر اثشة 
فوق قار عة الزمان قصيدة..

وليحتفل بك كل من لم يمتلك

$$
\text { ذكرى }
$$

لا تنكسر ! لا .. تنتصر ، وكن

بين بين

$$
\begin{aligned}
& \text { معلقا. فأذا انكسرت انكسرنا } \\
& \text { و إذا انتصرت كسرتنا، و هدمت } \\
& \text { هيكلنا. } \\
& \text { إذاً، كن ميتا حيا! } \\
& \text { وحيا ميتا } \\
& \text { ليو اصل الكهان مهنتهم مئا } \\
& \text { وكن طيفا خفيا. } \\
& \text { ولتبق وحدك عاليا } \\
& \text { لا يلمس الزمن التقيل وحن عاليا } \\
& \text { مجالك الجوي. } \\
& \text { فاصعد ما أستطعت } \\
& \text { فأنت أجملنا شهيدا. } \\
& \text { كن بعيدا ما استطعت لكي نرى } \\
& \text { في الوحي ظللك، أرجواني } \\
& \text { الخريطة الوبة } \\
& \text { فالسلام عليك يوم ولدت } \\
& \text { في بلد السلام } \\
& \text { ويوم مت، ويوم تبعث من ظلام } \\
& \text { الموت حيا (109)(تيوم من }
\end{aligned}
$$

ان (( البشارة )) هي المسيح ، و الرؤيـا (( عـالم الغيب و الثـهادة )) التي جـاء بها المسيح

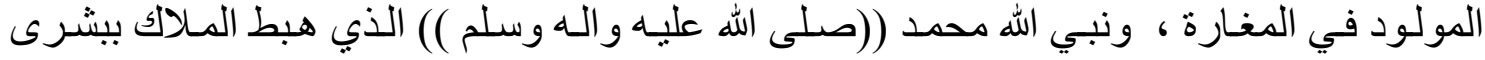


الاسلام في غار (( حر اء )) وينتهي درويش هذا المقطع بتناص قر آني من سورة (( مريم )) وفي ) وفي

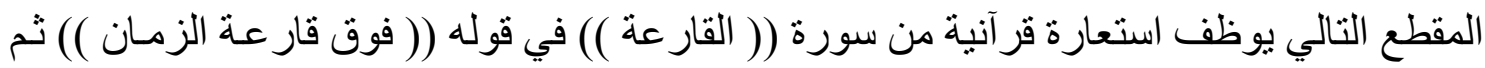

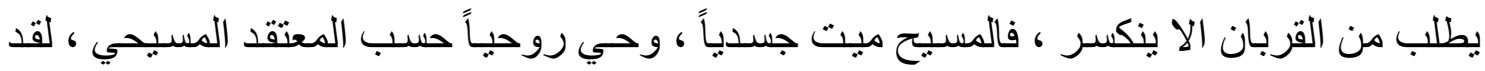

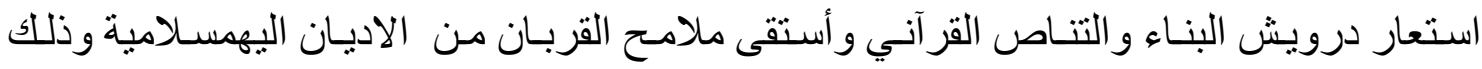
القربان هو المسيح الذي ينتظر اليهود و المسيحيون و المسلمون ، فهو المنقذ الذي يخلصهم من الظلم

1. وظف السياب ومحمود درويش شخصية المسيح بوصفها رمز اً لمعانـاة الالم الجسدي وقد

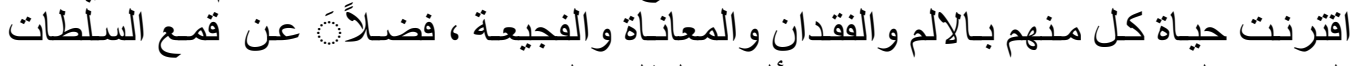

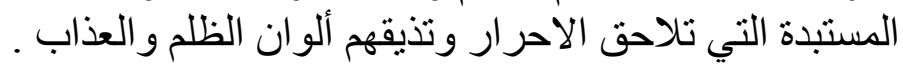

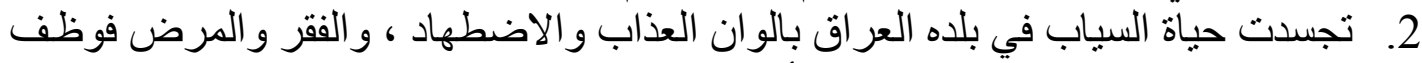

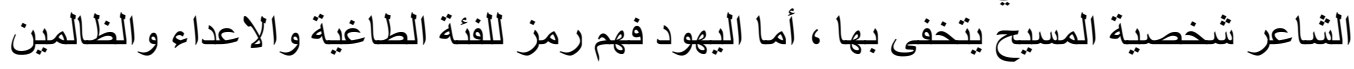

3. ت تتجلى صورة الموت من أجل البقاء عند السياب ودرويش ، وتشـع تلك الصـور الثـعرية

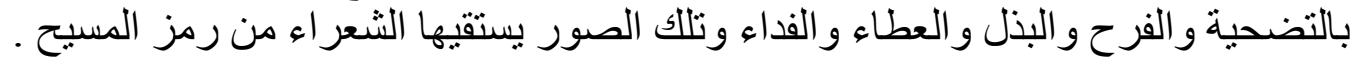

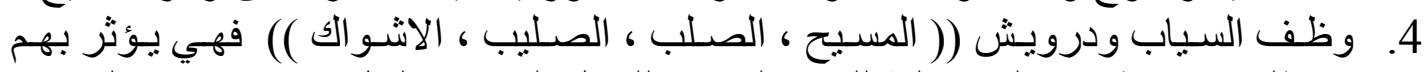

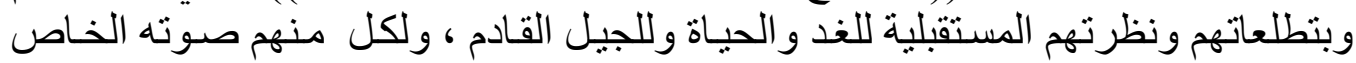

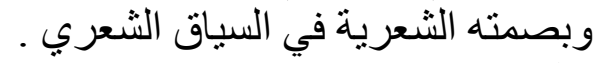

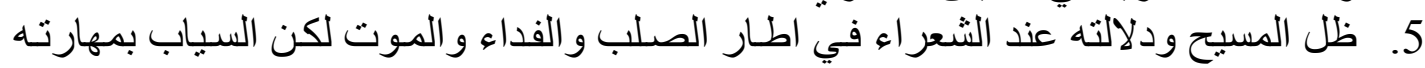

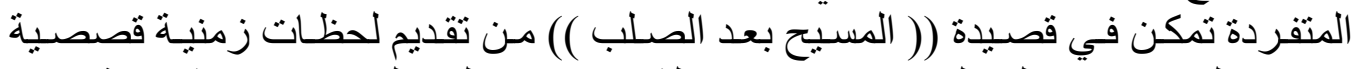

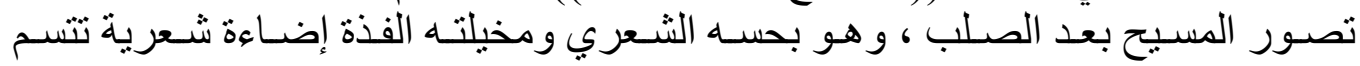
بحضور جمالي .

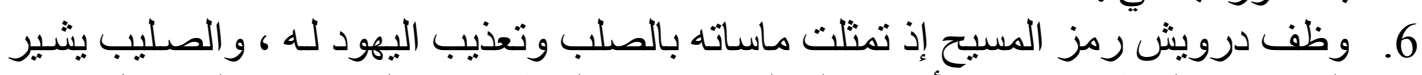

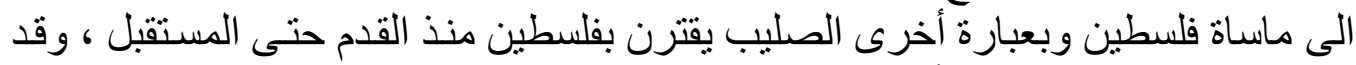

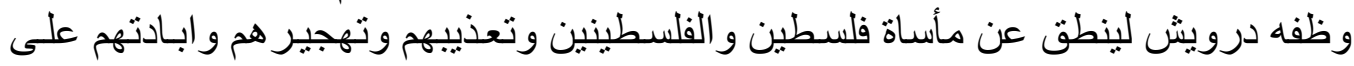

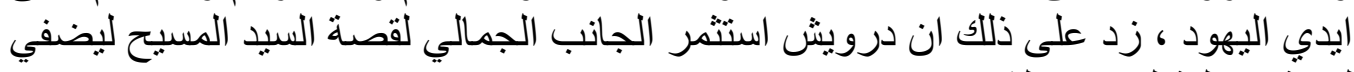

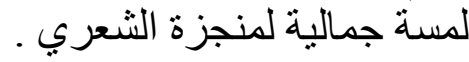

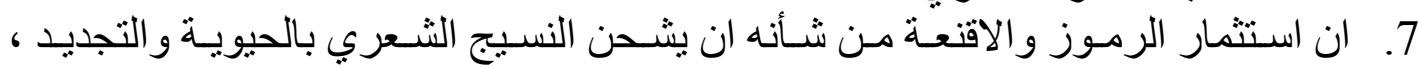

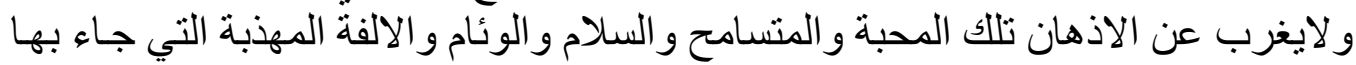

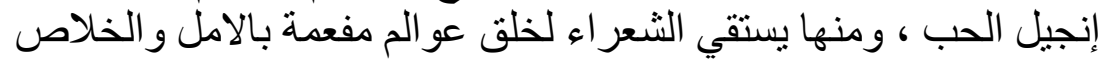

$$
\text { الهو امش :- (1) - n }
$$

1.

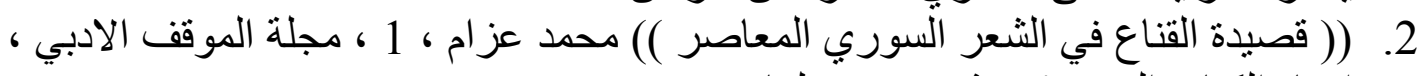

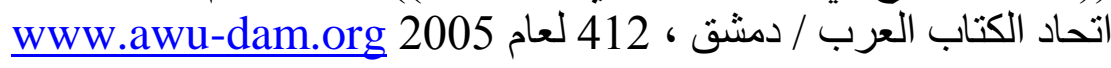


3. ينظر : اتجاهات الثعر العربي المعاصر / د. احسان عباس : 154.

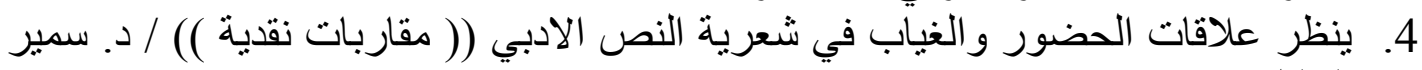

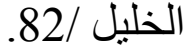

5. القصيدة الطويلة في الثُعر العربي المعاصر / د. د. احمد زهير : 144. 6. القصيدة الطويلة في الشعر العربي المعاصر : 145. 7. بنظر : المصدر السابق: 145.

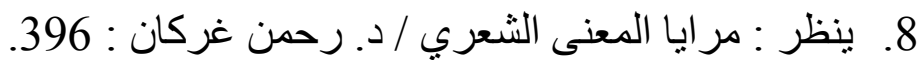
9. الاعمال الثعرية الكاملة / السياب :31.

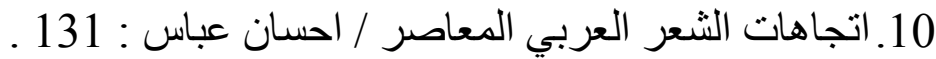
11.ينظر : الاسطورة في شعر السياب / عبد الرضا علي : 104-105 .

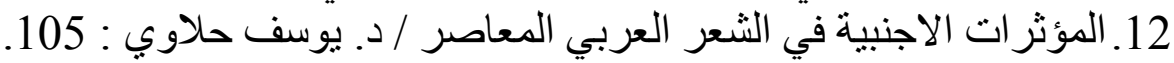

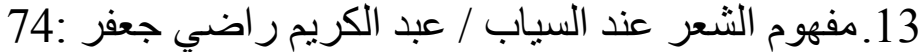

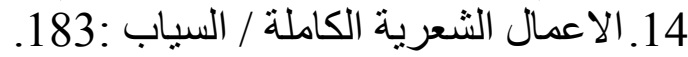
15. الاعمال الثعرية الكاملة السياب : 204. 16. 15 الاعمال الثعرية الكاملة السياب : 186.

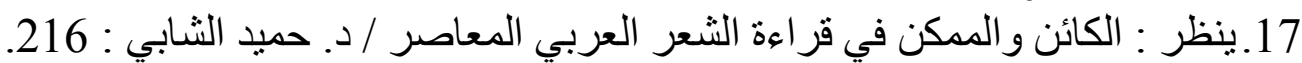

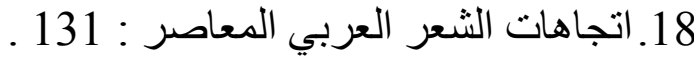

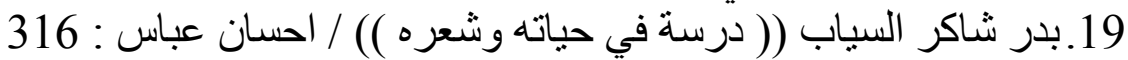
20. الاعمال الثعرية الكاملة السياب : 245-246 21 21. الاسطورة في شعر السياب : 127 22. الاسطورة في شعر السياب : 128 . 123 23. (( بنية القناع في القصيدة العربية المعاصرة )) / خليل الموسى : 6 ، مجلة املوقف الادبي

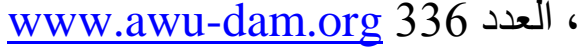

24. ينظر بدر شاكر السياب / ريتا عوض : 236

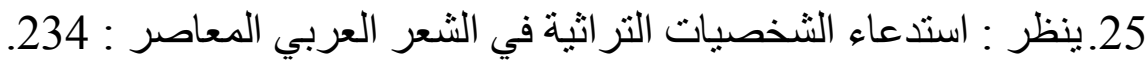
26. الاعمال الشعرية / السياب : 246.

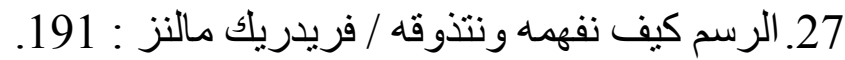
28. ينظر : جماليات اللون في السينما / سعد عبد الرحمن : 44.

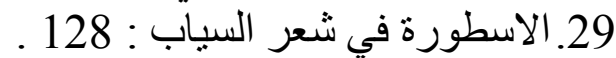
30.ينظر : الاسطورة في شعر السياب : 174-178

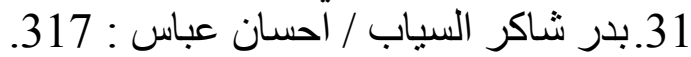

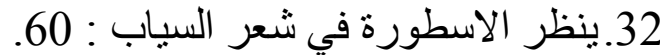

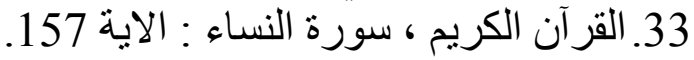

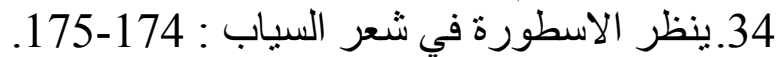

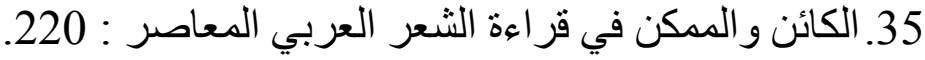

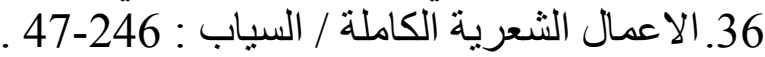
37.ينظر استدعاء الثخصيات التراثية في الثعر العربي المعاصر : 235. 
38.ينظر : السياب / عبد الجبار عباس : 142.

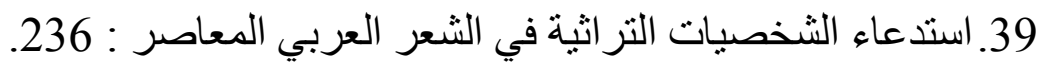

40. الاعمال الشعرية الكاملة / السياب : 247

41. السياب / عبد الجبار عباس : 117-118 ـ

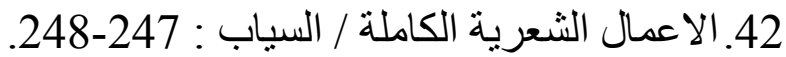

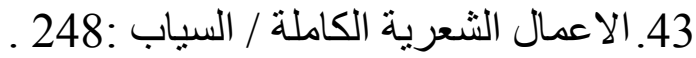

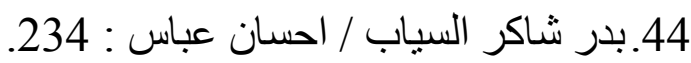

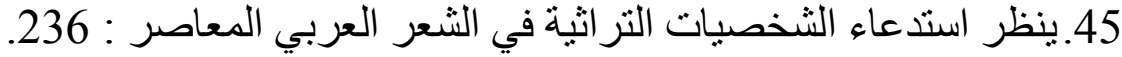

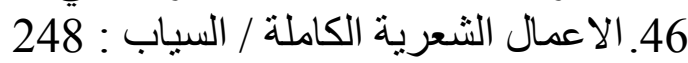

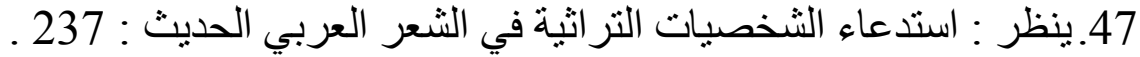

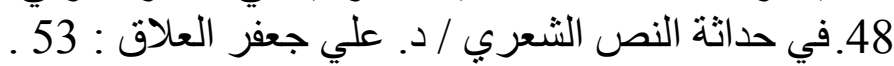
49.ينظر : المصدر السابق: 53 ـ 53

50. في حداثة النص الثنعري : 49

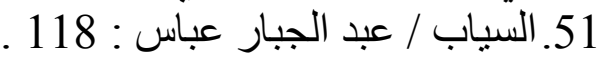

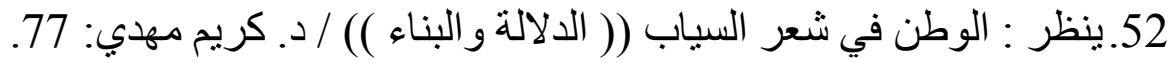

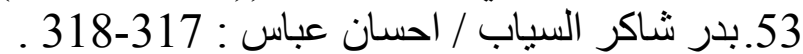

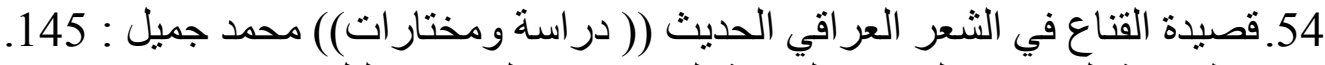

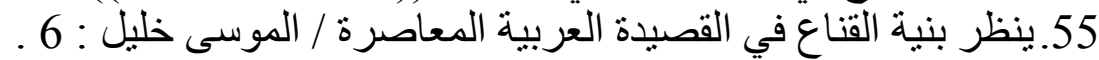

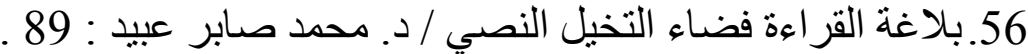

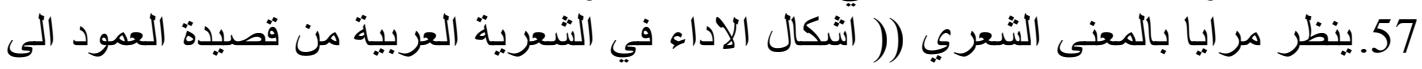

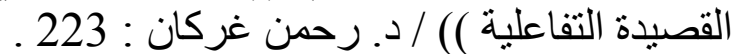

58. ينظر : التور اتيات في شعر محمد درويش (( من المقاومة التي التسوية )) / / احمد اشقر

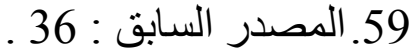

60. المصدر السابق : 38 ـ 38 ومابعدها .

61. 6يظر المصدر السدابق : 42 .

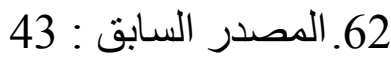

63. التور اتيات في شعر محمود درويش : 46 ـ 43 ـ

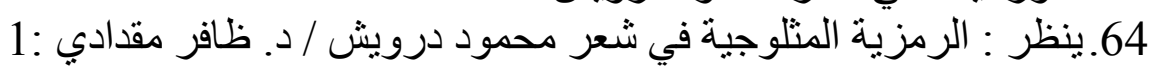

65. ينظر : التور اتيات في شعر محمود درويش : 47-51.

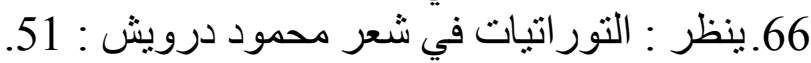

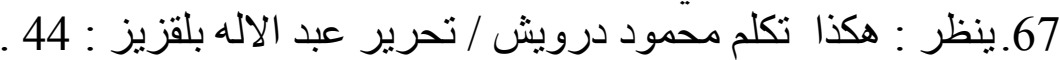

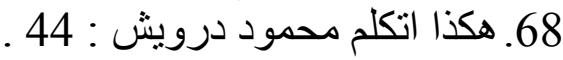

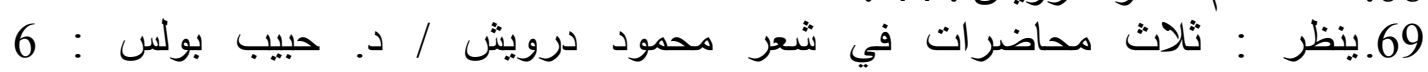

WWW.factinirag.com/archiv/portal

70. هكذا تكلم محمود درويش : 47 . 40.

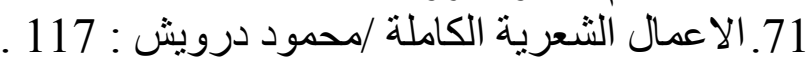


72.الرمزية المثيولوجية في شعر محمود درويش والصراع على ذاكرة المكان : 1 http//m.almothaqaf.com 73. ينظر : التور اتيات في شعر محمود درويش من المقاومة الى التسوية : 52 ـ. 46 : 74. 73

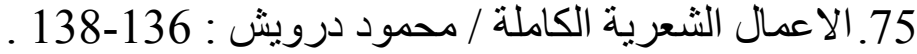

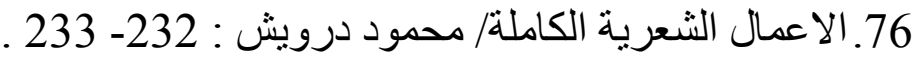

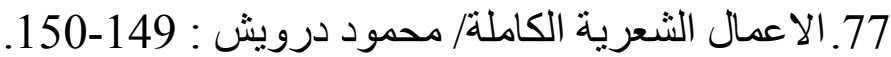

78. الاعمال الثعرية الكاملة / محمود درويش : 120 : 120 :

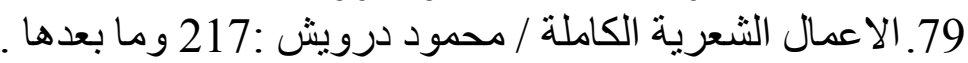

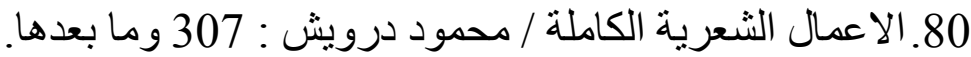

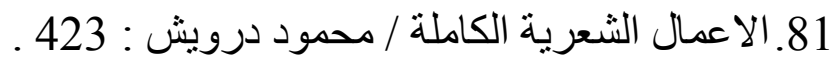

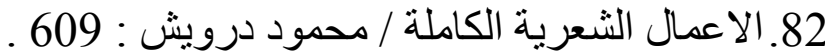
83. الاعمال الثعرية الكاملة / محمود درويش / محود درويش : 617 و وما بعدها

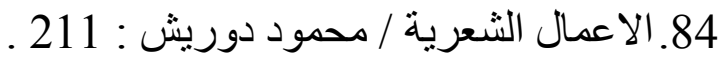

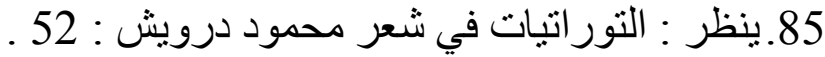

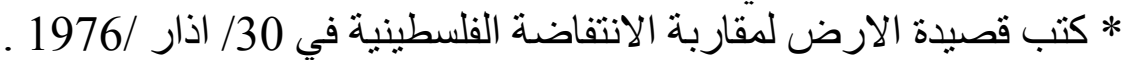

86 86 8نظر : هكذا تكلم محمود درويش: 90. . www.arabicnadwah.comarab.potes/darwish.htm 88. ينظر : هكذا تكلم محمود درويش : 46.

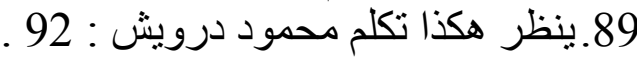

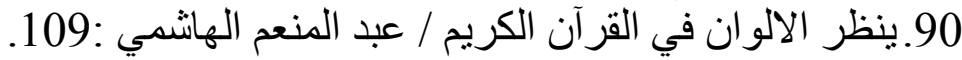

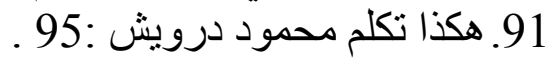

92. ينظر:الرمزية المثيولوجية في شعرد شئ محمود درويش والصراع على ذاكرة http//almothagaf.com 2 93. قصيدة مديح العالي / محمود درويش

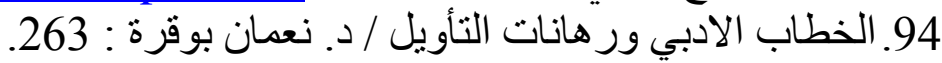

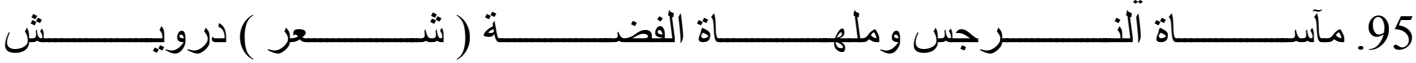
. WwW.darwishfounation,org/attemplak,php 96.ينظر : مر ايا المعنى الشعري : 193 .

97. 9نظر : 96 التوراتيات في شعر محمود درويش : 47

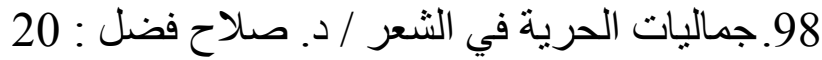

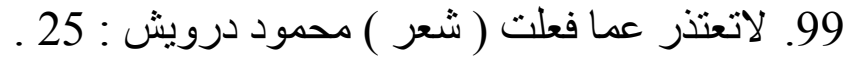

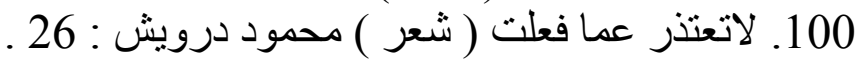
101 100.جماليات الحرية في الشعر : 23 102.مر ايا المعنى الثعري : 209-210 


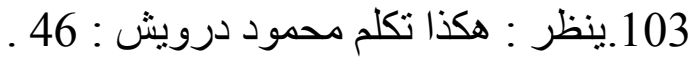

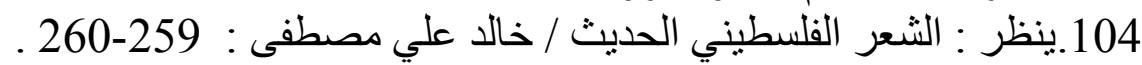

105.ينظر : الثعر الفلسطيني الحديث : 280 ـ

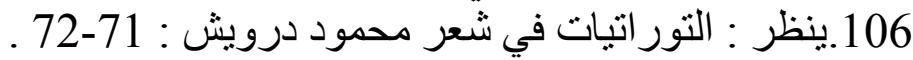

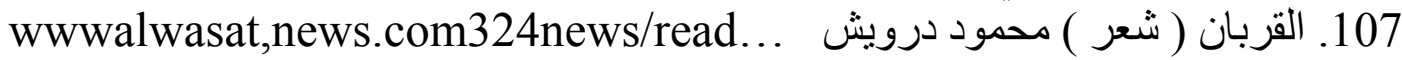

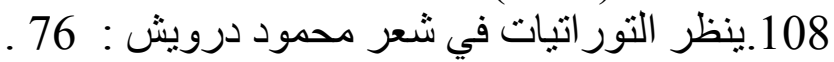

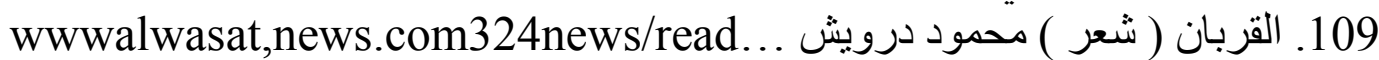
110 10نظر : التور اتيات في شعر محمود درويش : 84- 86 ـ

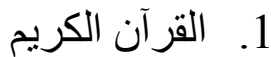

2. اتجاهات الشعر العربي المعاصر / د. د. احسان عبـاس ، المجلس الوطني للثقافة والفنون ، الكويت ، 1978.

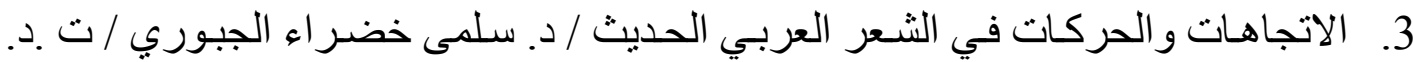

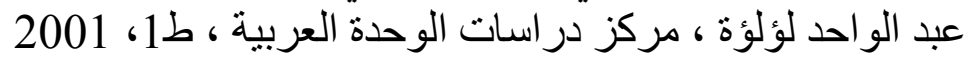

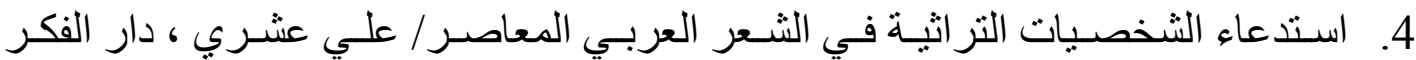

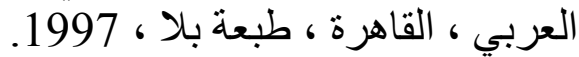

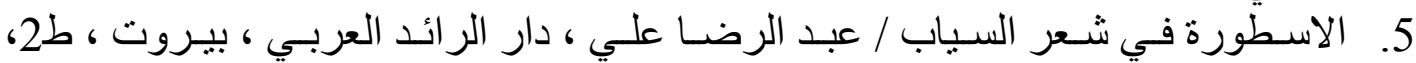
.1984 6. الاعمال الثعرية الكاملة / السياب ـ تقديم نـاجي علوش ، دار الحريـة للطباعـة ، بغداد ، ط4، 2008 . 200 7. الاعمال الشعرية الكاملة / محمود درويش ، المؤسسة العربية للار اسـات و النشـر ، بيروت

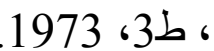

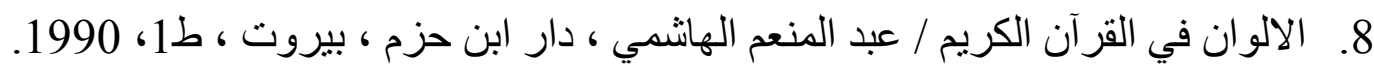

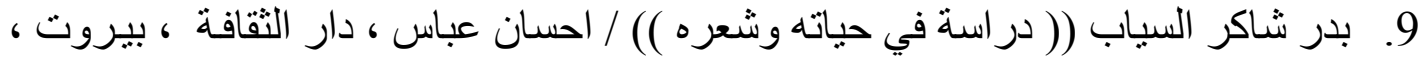
ط2، 1972. 19

10. بدر شاكر السياب / ريتا عوض / المؤسسة العربية للار اسـات و النشـر ، بيروت ، المكتبـة

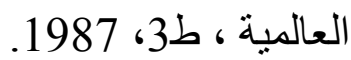
11. بلاغة القراءة فضاء المتخيل النصي / ـ ـ محمد صـابر عبيد ، عـالم الكتب الحديثة ، اربد ،

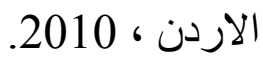

12. التور اتيات في شعر محمود درويش (( من المقاومة الى التسوية )) / أحمد اشقر ، قدمس

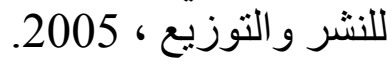

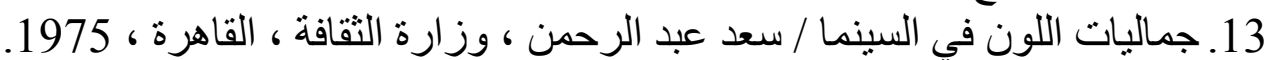

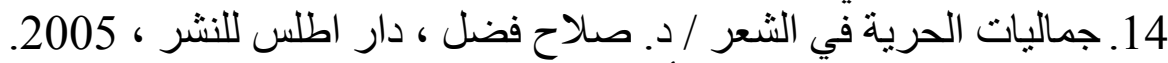

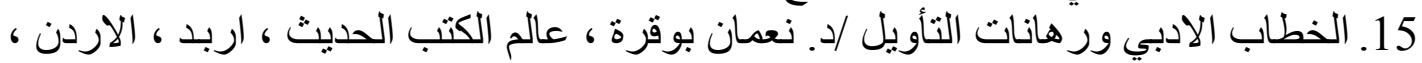
.2012

16. الرسم كيف نفهمه ونتذوقه/فردريك مالتز ، دار الثؤون الثقافية العامة، بغداد، 1993. 
17. السياب/ عبد الجبار عباس ، دار الحرية للطباعة ـ مطبعة الجمهورية ، بغداد ، داعة 1972.

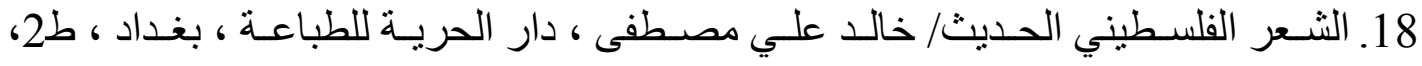
.1986

19. علاقات الحضور و الغياب في شعرية النص الادبي (( مقاربات نقدية )) / د. سمبر الخليل

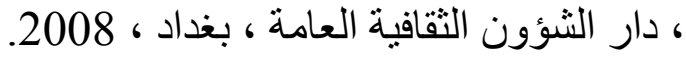

20. في حداثـة النص الثـعري / د. علي جعفر العـلاق ، دار الثـروق للنشـر ، الاردن ، ط1، 2003

21. قصيدة القتـاع في الثـعر العر اقي الحديث (( در اســة ومختـار ات )) / محمد جميـل ، دار

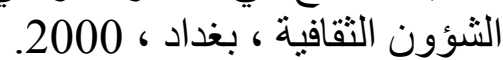

22. القصبدة الطويلة في الشعر العربي المعاصر / لـونة د. أحمد زهير رحاحله ، دار الحامد للنشر

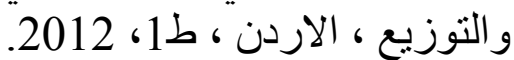

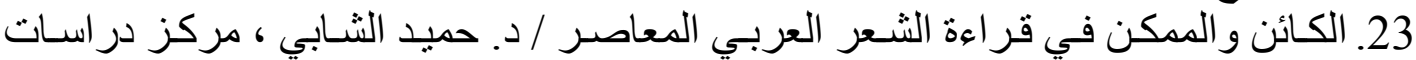

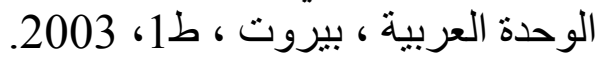

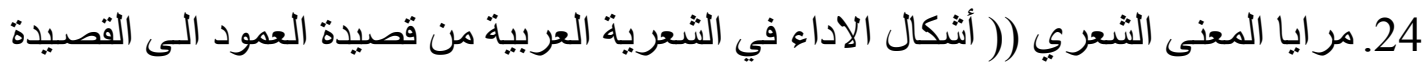

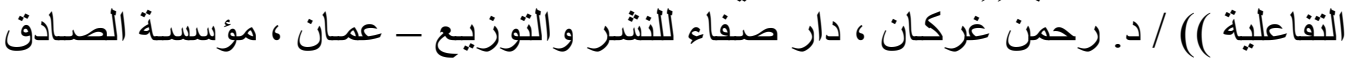
الثقافية، ط2012/12.

25. مفهوم الثعر عند السياب / عبد الكريم ر اضي جعفر ، دار الثؤون الثقافية العامة ، بغداد

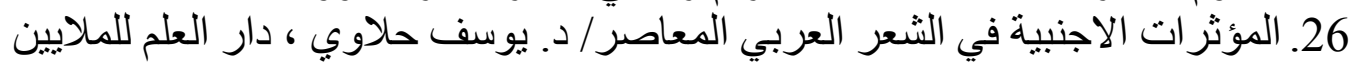

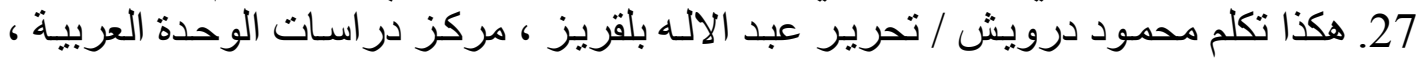

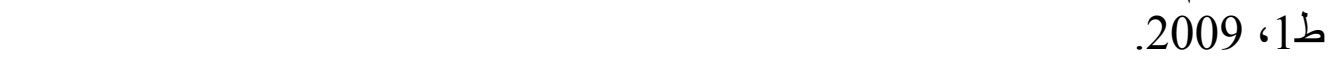
28. الـوطن في شـعر السـياب (( الدلالـة والبنـاء )) / د. كـريم مهـدي المسـودي ، صـفحات

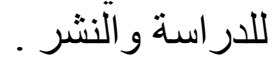
قاعدة البيانات والانترنت : للتر :

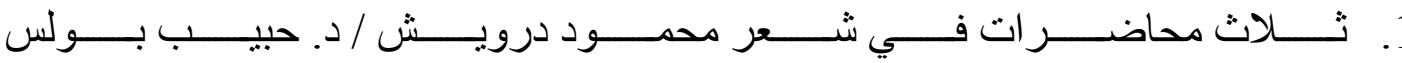
WWW.factinirag.com/archiv/portal 2. الرمزية المثيولوجية في شعر محمود درويش والصراع على ذاكرة المكان http//m.almothaqaf.com

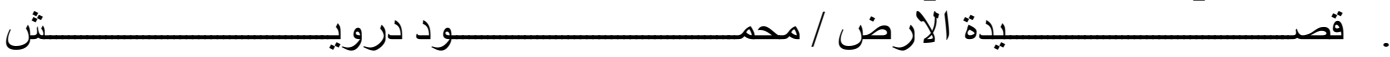

.www.arabicnadwah.comarab.potes/darwish.htm 4.

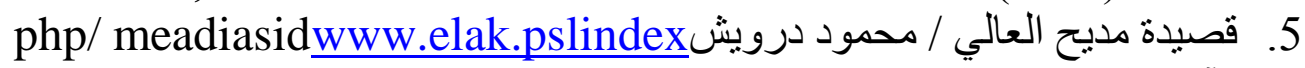

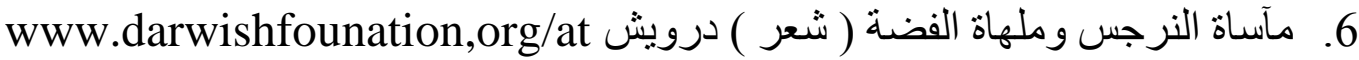

